\title{
33. GEOCHEMISTRY AND MINERALOGY OF BASALTS FROM THE GALAPAGOS SPREADING CENTER, DEEP SEA DRILLING PROJECT LEG 54
}

\author{
David P. Mattey, ${ }^{1}$ Department of Geology, Bedford College, London, England \\ and \\ I. D. Muir, Department of Mineralogy and Petrology, The University of Cambridge, Downing Place, \\ Cambridge CB2 3EW, England
}

\begin{abstract}
Basalts drilled at Site 424 and Hole 425 near the Galapagos Spreading Center at $86^{\circ} \mathrm{W}$ are moderately evolved basalts and ferrobasalts characteristic of the non-rifted ridges in the eastern Pacific. Three distinct chemical types occur at Hole 425 , but only one type, a ferrobasalt, occurs in all four holes at Site 424. Despite strong enrichment of $\mathrm{Fe}, \mathrm{Ti}, \mathrm{Zr}$, and the rare-earth elements, these basalts are similar to depleted mid-ocean ridge basalts and were therefore generated within a depleted mantle source. Electron-microprobe mineral analyses were obtained on several samples; one from Site 424 was intensively studied. The variations in groundmass pyroxene compositions within the single sample are almost equivalent to the entire variation observed in all the Galapagos basalts. Phenocryst compositions are used to model least-squares crystal fractionation among the basalts. Although satisfactory fits to major-oxide compositions can be obtained by fractionating mainly plagioclase and clinopyroxene plus minor olivine, this fails to account for the levels of certain trace elements in the most evolved basalts of Hole 425 . Instead of fractionation, we believe that mixing of ferrobasalts with more primitive basalts explains these variations more satisfactorily.
\end{abstract}

\section{INTRODUCTION}

The unscheduled drilling program in the Galapagos area provided the first stratigraphic sampling of young basalt erupted along the Galapagos Spreading Center (GSC). The latter forms the central segment of an eastwest trending spreading axis which extends from the triple junction intersection of the Pacific, Cocos, and Nazca lithospheric plates. The ridge, at $86^{\circ} \mathrm{W}$, is a relatively smooth feature with a poorly defined axial rift valley. Basalts were successfully recovered at two sites drilled on either side of the spreading ridge axis at $86^{\circ} \mathrm{W}$ (Figure 1).

Site 424 is situated in the "Mounds Hydrothermal Field" $22 \mathrm{~km}$ south of the ridge axis in about 2700 meters water depth. Four holes were drilled about 300 meters apart along a north-south line into crust 0.60 to 0.62 m.y. old. Drilling conditions in this area were unusually bad, resulting in only limited penetration and poor recovery of basaltic basement. The maximum basement penetration of 45 meters was achieved in Hole $424 \mathrm{~A}$, with a recovery of 8.5 meters of basalt.

\footnotetext{
${ }^{1}$ Present address: Department of Geological Sciences, The University of Birmingham, Birmingham B15 2TT, England.
}

Hole 425 was drilled in 2850 meters of water $62 \mathrm{~km}$ north of the GSC, where the basement age is $1.8 \mathrm{~m} . \mathrm{y}$. Penetration at this site was 30 meters, and 8 meters of basalt was recovered.

Dredge hauls and DSDP drilling have revealed that basalts erupted along the Cocos-Nazca Ridge and GSC (e.g., Schilling et al., 1976), and along both limbs of the East Pacific Rise - that is, the Pacific-Cocos Rise, including the Siqueiros area (e.g., Batiza et al., 1977) and the Pacific-Nazca Rise (e.g., Bunch and Laborde, 1976) - are commonly geochemically evolved ferrobasalts. Kay et al. (1970) suggested that these high-iron tholeiites (containing up to $20 \%$ iron as $\mathrm{FeO}$ ) were generated from normal mid-ocean ridge basalt (MORB) by extensive crystal fractionation. Subsequently, Clague and Bunch (1976) and Batiza et al. (1976) have shown - using graphical subtraction diagrams, computer leastsquares mixing programs, and phosphorus fractionation calculations - that ferrobasalt can be produced from unfractionated MORB by up to 80 per cent fractional crystallization of plagioclase, clinopyroxene, and minor olivine.

In this chapter, electron-microprobe analyses of phenocrysts and groundmass minerals, and whole-rock analyses for major and rare-earth elements are reported for representative basalts from Holes 424 (six samples), 


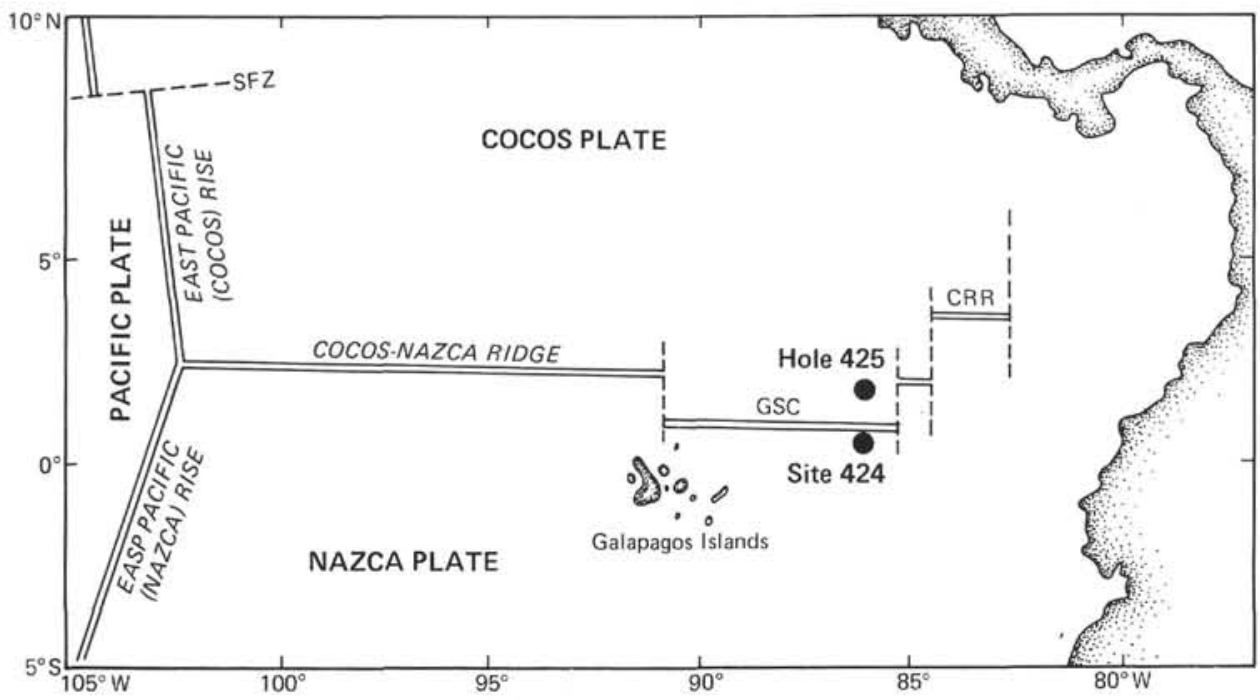

Figure 1. Map of the Galapagos area, showing the localities of Site 424 and Hole 425. GSC = Galapagos Spreading Center; $C R R=$ Costa Rica Rift; SFZ = Siqueiros fracture zone.

424B (two samples), and 425 (five samples). These data are used to test and develop the fractional crystallization models advanced by Clague and Bunch (1977) and Batiza et al. (1976), paying particular attention to the behavior of the trace elements.

\section{SAMPLING AND ANALYTICAL METHODS}

The rare-earth elements were determined by instrumental neutron activation analysis (Gordon et al., 1968 ), using a $\mathrm{Ge}(\mathrm{Li}) 1-\mathrm{cm}^{3}$, low-energy photon detector at the Department of Geology, Bedford College. Spectra were processed using the standard peak resolving program SAMPO (Routi, 1969), and the results were corrected for flux variation and half life. The precision of the method is considered to be better than 20 per cent for $\mathrm{Nd}, 10$ per cent for $\mathrm{Yb}, \mathrm{Gd}, \mathrm{Ta}, 5$ per cent for $\mathrm{Ce}$, $\mathrm{Tb}, \mathrm{Tm}$, and 2 per cent for Eu and $\mathrm{Hf}$.

Analyses of major silicate phases were obtained for 13 representative basalts from the GSC using the energy-dispersive electron-microprobe analyzer at the Department of Mineralogy and Petrology, Cambridge. Details of the technique along with accuracy and precisions are reported elsewhere (Mattey et al., 1980). Samples lacking shipboard XRF data were analyzed for major oxides, using classical wet-chemical methods by $\mathrm{J}$. H. Scoon at the Department of Mineralogy and Petrology, Cambridge.

\section{LITHOLOGY AND PETROGRAPHY}

Detailed descriptions are to be found in the relevant Site Reports. The more pertinent features are discussed below.

\section{Site 424}

Basalts from all the four holes drilled at this site are petrographically similar, containing sparse phenocrysts of plagioclase $\left(\mathrm{An}_{75}\right)$, with very rare olivine $\left(\mathrm{Fo}_{72-76}\right)$ and clinopyroxene. Plagioclase phenocrysts are usually euhedral, often with complex zoning and overgrowths. Phenocrysts of clinopyroxene are also euhedral, some displaying simple twinning. Olivine, when present, is completely fresh.

The basalts were generally massive, with few glassy margins; they display a wide range of textural differences depending on the degree of undercooling. The groundmass contains plagioclase, clinopyroxene, titanomagnetite, and glass, with minor secondary minerals. The glass is usually devitrified but is relatively fresh. The few vesicles present $(2-3 \%)$ are lined or infilled with clays or iron oxides.

\section{Hole 425}

Despite the poor basement recovery at this site, within the 30 meters of basement penetrated, 12 cooling units were recognized by the shipboard scientists. However, there is no firm evidence whether any of these are intrusive or extrusive in origin. The basalts are further divided into eight lithological units (referred to as Units $\mathrm{L} 1, \mathrm{~L} 2, \mathrm{~L} 3$, etc.) according to the nature and abundance of the phenocryst phases present.

\section{Unit L1}

This unit is plagioclase sparsely phyric basalt. A finegrained basalt containing up to 3 per cent euhedral, slightly zoned plagioclase phenocrysts. Vesicles are concentrated in the middle of the unit, locally forming up to 15 per cent of the rock.

\section{Unit L2}

This unit is plagioclase-clinopyroxene sparsely phyric basalt. The basalt contains up to 5 per cent plagioclase phenocrysts with minor euhedral clinopyroxene. Plagioclase phenocrysts are strongly zoned and contain glass inclusions. 


\section{Unit L3}

This unit is plagioclase phyric basalt and is characterized by containing from 15 to 20 per cent of plagioclase phenocrysts, with minor olivine and clinopyroxene. Plagioclase forms both euhedral single crystals and glomerocrysts that are significantly more calcic than those from other units.

\section{Unit L4}

This unit is plagioclase-clinopyroxene-olivine sparsely phyric basalt. Basalts from this unit are similar to those from Unit 2, with the exception that rare olivine phenocrysts are also present. The upper contact of this unit is poorly defined, and it is possible that Units L2, L3, and L4 are part of the same cooling unit. The concentrations of phenocrysts in Unit L3 may have resulted from flow differentiation (see the later section in this paper "Mineral Chemistry").

\section{Unit L5}

This unit is plagioclase-clinopyroxene sparsely phyric basalt. Relatively glassy basalts contain skeletal microphenocrysts of plagioclase and rare clinopyroxene.

\section{Unit L6}

This unit is plagioclase sparsely phyric basalt.

\section{Unit $\mathbf{L 7}$}

This unit is plagioclase-olivine sparsely phyric basalt. This basalt contains glomerophyric aggregates of slightly zoned plagioclase and subhedral olivine.

\section{Unit L8}

This unit is plagioclase sparsely phyric basalt and is relatively coarse grained and almost holocrystalline.

The basalts from Hole $\mathbf{4 2 5}$ are slightly more altered than those from the Mounds Hydrothermal Field, Site 424. Weathered surfaces are common and are coated with thin crusts of iron oxides, smectites, or carbonates. Oxidative weathering penetrates the basalts from these surfaces to a depth of about $1 \mathrm{~cm}$. Mild hydrothermal alteration has resulted in the partial replacement of olivine by iron oxides and in the formation of thin veins containing smectites, carbonates, pyrite, and minor chalcopyrite. The abundances of these secondary phases increase approximately with depth.

\section{RESULTS}

\section{Whole-Rock Geochemistry}

Major oxide and rare-earth element analyses are presented in Table 1. The rare-earth data, normalized to chondrites, are plotted in Figure 2.

\section{Site $\mathbf{4 2 4}$}

The analyses of basalts from the transect of four holes drilled across the Mounds Hydrothermal Field reveal very little variation in composition. These basalts are typically quartz-normative tholeiites containing 6 to 7 per cent $\mathrm{MgO}, \sim 13$ per cent $\mathrm{Al}_{2} \mathrm{O}_{3}$, and $\sim 10$ per cent $\mathrm{CaO}$, and are characterized by relatively high contents of total iron $(\sim 13$ per cent as $\mathrm{FeO})$ and $\mathrm{TiO}_{2}(1.9$ per cent). High contents of $\mathrm{Zr}(\sim 120 \mathrm{ppm})$ and the low abundances of compatible trace elements such as $\mathrm{Ni}$ $(\sim 70 \mathrm{ppm})$ suggest that these basalts are considerably more fractionated than normal mid-ocean ridge basalts (MORB).

A number of elements, however, suggest that these iron-rich tholeiites, or ferrobasalts, are fundamentally similar to MORB. The very low abundances of $\mathrm{Na}_{2} \mathrm{O}$ $(\sim 2 \%), \mathrm{K}_{2} \mathrm{O}(<0.08 \%), \mathrm{Sr}(\sim 65 \mathrm{ppm})$, and $\mathrm{Rb}(<0.5$ ppm) - and particularly the ratio of elements such as $\mathrm{Ti} / \mathrm{Zr}(\sim 100)-$ are typical of most MORB. The fractionated MORB character of these ferrobasalts is emphasized by the rare-earth element (REE) data (Figure 2). Although containing relatively high overall abundances of REE (e.g., $\mathrm{Ce}_{\mathrm{N}} \sim 12, \mathrm{Yb}_{\mathrm{N}} \sim 20$ ), the light REE are strongly depleted relative to the heavy REE, with a $\mathrm{Ce}_{\mathrm{N}} / \mathrm{Yb}_{\mathrm{N}}$ ratio $\sim 0.6$.

The wet-chemical analyses of major oxides (Table 1) are very similar to those obtained by the XRF method. The low contents of water and the low oxidation state of the iron confirm the overall freshness of these basalts.

\section{Hole 425}

The basalts from this hole display a small range in composition (Table 1) and are divided into three chemical groups (see below). A general comparison with the ferrobasalts from Site 424 reveals that $\mathrm{MgO}(7-8 \%)$, $\mathrm{CaO}(11-12 \%), \mathrm{Al}_{2} \mathrm{O}_{3}(13.5-15 \%)$, and $\mathrm{Ni}(50-80 \mathrm{ppm})$ are higher, and total iron $(9-12 \%$ as $\mathrm{FeO}), \mathrm{TiO}_{2}$ (1-1.4\%), the alkalies (e.g., $\mathrm{Na}_{2} \mathrm{O} 1.8-2.2 \%$ ), and $\mathrm{Zr}$ $(50-70 \mathrm{ppm})$ are all lower in the basalts from Hole 425 . Being only slightly quartz-normative, the latter basalts are therefore generally less fractionated than those from Site 424 and are closer in composition to "normal" MORB.

The full shipboard XRF analyses (see Site Report) reveal two major compositional breaks occurring between Lithological Units L1 and L2 and between Units L4 and L5. Three chemical units $-\mathrm{C} 1(=\mathrm{L} 1), \mathrm{C} 2$ $(=\mathrm{L} 2, \mathrm{~L} 3$, and L4), and C3 (= L5, L6, L7, and L8) are therefore recognized.

The lowest unit (Unit C3) contains the least evolved rocks from this hole. They are characterized by an $\mathrm{Fe} / \mathrm{Mg}$ ratio of $\sim 1.3$ and contain $\sim 1$ per cent $\mathrm{TiO}_{2}$ and 65 to $72 \mathrm{ppm} \mathrm{Ni}$. The sparsely phyric basalts from Unit L2 have a slightly higher average $\mathrm{Fe} / \mathrm{Mg}$ ratio (1.4) and contain $\sim 1.2$ per cent $\mathrm{TiO}_{2}$ and 60 to $64 \mathrm{ppm} \mathrm{Ni}$. The porphyritic basalts from Lithological Unit L3 within Unit $\mathrm{C} 2$ are relatively enriched in $\mathrm{CaO}$ and $\mathrm{Al}_{2} \mathrm{O}_{3}$; they are somewhat poorer in most other elements as a result of the high modal abundances of plagioclase (up to $20 \%$ ) in these samples. The uppermost Unit C1 contains the most evolved basalts from this hole, with $\mathrm{Fe} / \mathrm{Mg}$ ratios of $\sim 1.6$ and with the highest content of $\mathrm{TiO}_{2}$ $(1.4 \%)$ and the lowest abundances of $\mathrm{Ni}(48 \mathrm{ppm})$. Thus, at Hole 425 , the degree of fractionation increases with stratigraphic height.

The systematic chemical variation between Units $\mathrm{C} 1$, $\mathrm{C} 2$, and $\mathrm{C} 3$ is illustrated in Figures 3 and $4-$ plots of $\mathrm{FeO}$ versus $\mathrm{MgO}$, and $\mathrm{Ti}$ versus $\mathrm{Zr}$, respectively. It can 
TABLE

Major Oxide and Rare-Earth Element Analyses, Site 424 and Hole 425

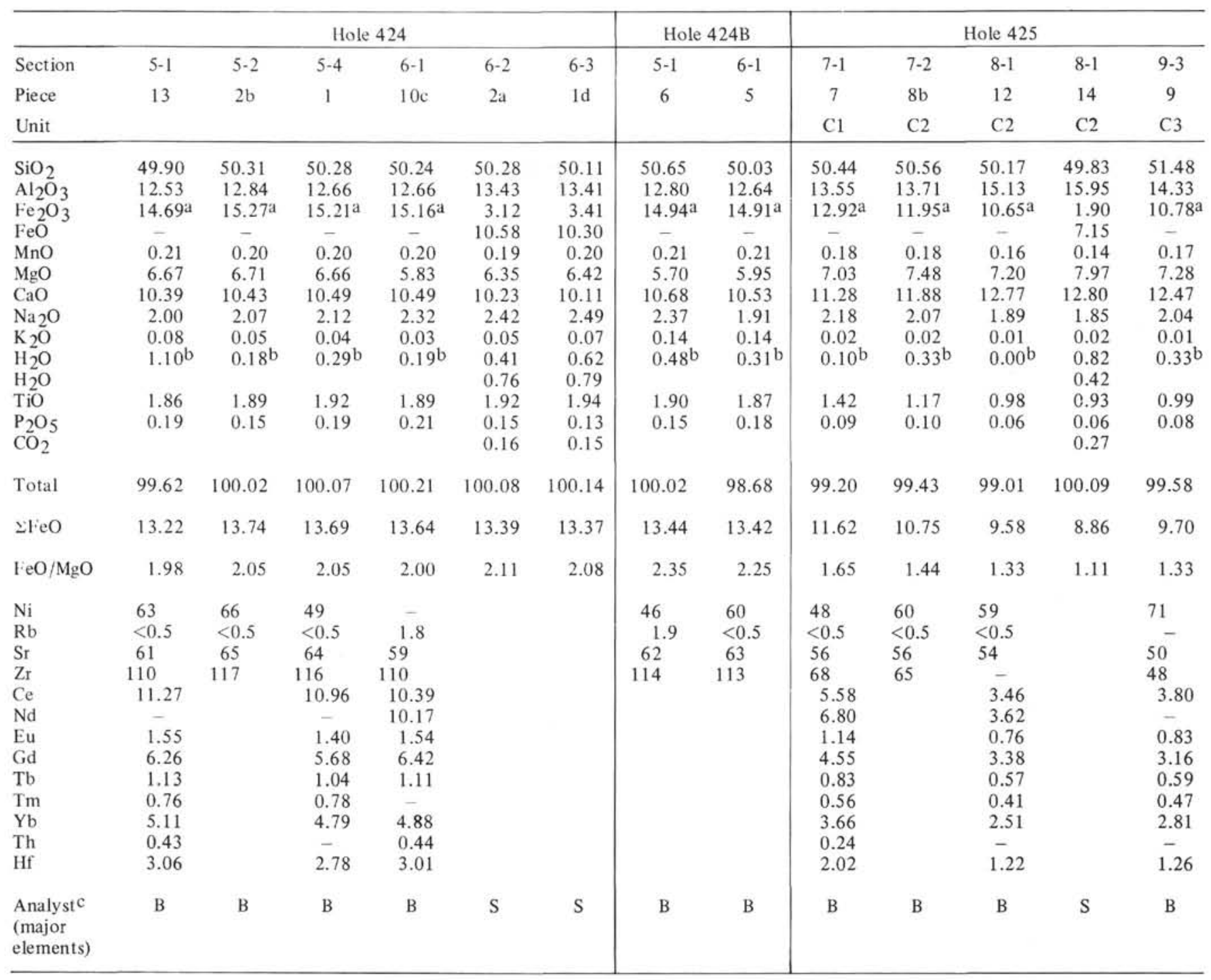

${ }_{b}^{\mathrm{a}}$ Total iron expressed as $\mathrm{Fe}_{2} \mathrm{O}_{3}$.

$\mathrm{b}$ Loss on ignition.

${ }_{B}$ : L. Briqueu; S: J. Scoon.

be seen from Figure 4 that the $\mathrm{Ti} / \mathrm{Zr}$ ratio of the Hole 425 basalts $(\sim 120)$ is slightly higher than that of the Site 424 ferrobasalts $(\sim 100)$.

The REE data (Figure 2) show that in general the basalts from Hole 425 not only have lower overall abundances (e.g., $\mathrm{Ce}_{\mathrm{N}}=4-6, \mathrm{Yb}_{\mathrm{N}}=11-17$ ) but also are more depleted in light $\mathrm{REE}\left(\mathrm{Ce}_{\mathrm{N}} / \mathrm{Yb}_{\mathrm{N}}=0.4\right)$. The normalized REE pattern of a basalt from Unit $\mathrm{C} 1$, however, is slightly less light-REE-depleted than the samples from Units $\mathrm{C} 2$ or $\mathrm{C} 3$.

\section{Mineral Chemistry}

\section{Plagioclase}

The results of 72 analyses of phenocryst and groundmass plagioclase crystals are summarized in Table 2 and Figure 5. Representative analyses are given in Table 3.
Plagioclase phenocrysts are generally rare in the Site 424 ferrobasalts. In the samples studied, phenocryst core compositions are relatively sodic and average $\mathrm{An}_{73}$. Although groundmass laths display a greater range of compositions, most examples fall in the range $\mathrm{An}_{70}$ to $\mathrm{An}_{50}$.

Plagioclase phenocrysts are more abundant in the basalts from Hole 425. Phenocryst core compositions are somewhat more calcic than those from the Site 424 ferrobasalts, ranging from $\mathrm{An}_{94}$ to $\mathrm{An}_{82}$. Phenocrysts from Unit $\mathrm{C} 3$ are, on average, slightly more calcic $\left(\mathrm{An}_{84}\right)$ than those from sparsely phyric samples from Units $\mathrm{C} 1$ and $\mathrm{C} 2\left(\mathrm{An}_{82}\right)$. Phenocrysts in the strongly phyric samples from Unit C2 (i.e., Lithological Unit L3) are significantly more calcic $\left(\mathrm{An}_{94}\right.$ to $\left.\mathrm{An}_{87}\right)$ than phenocrysts from the sparsely phyric basalts (i.e., L2 and L4) from Unit C2. 


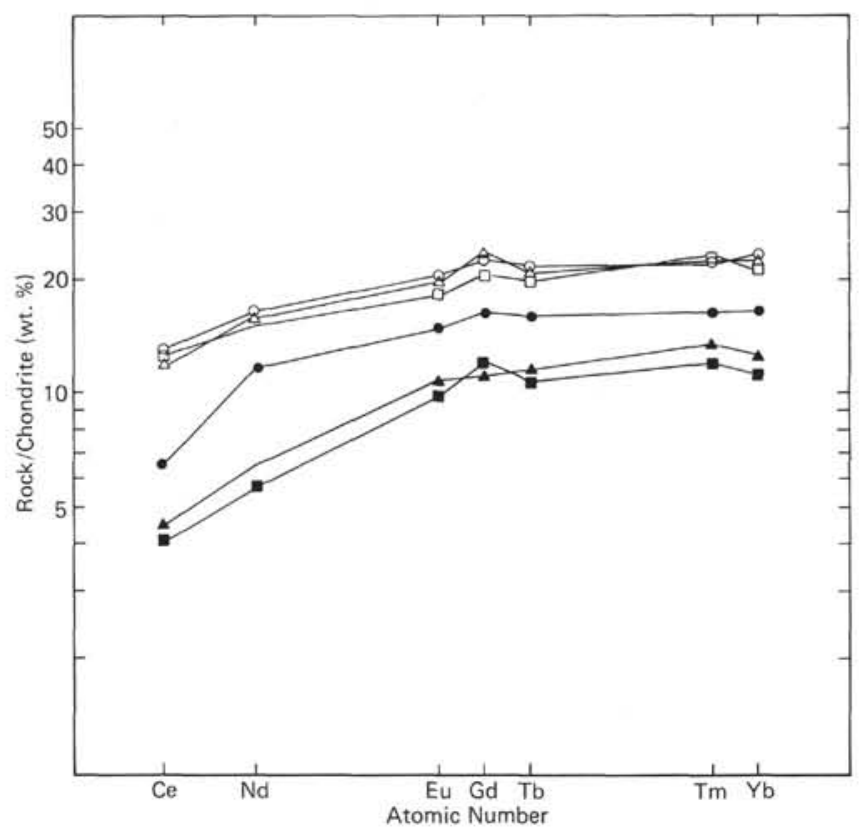

Figure 2. Rare-earth element abundances of Site $424 \mathrm{fer}-$ robasalts and Hole 425 basalts normalized to chondrites (Nakamura, 1974). Open symbols - Site 424 (Circle: Section 424-5-1 (Piece 13); square: Section 424-5-4 (Piece 1); triangle: Section 424-6-1 (Piece 10c). Closed symbols - Site 425 (Circle: Section 425-7-1 (Piece 7); square: Section 425-8-1 (Piece 12); triangle: Section 425-9-3 (Piece 9). (Source: Mattey and Muir, 1979).

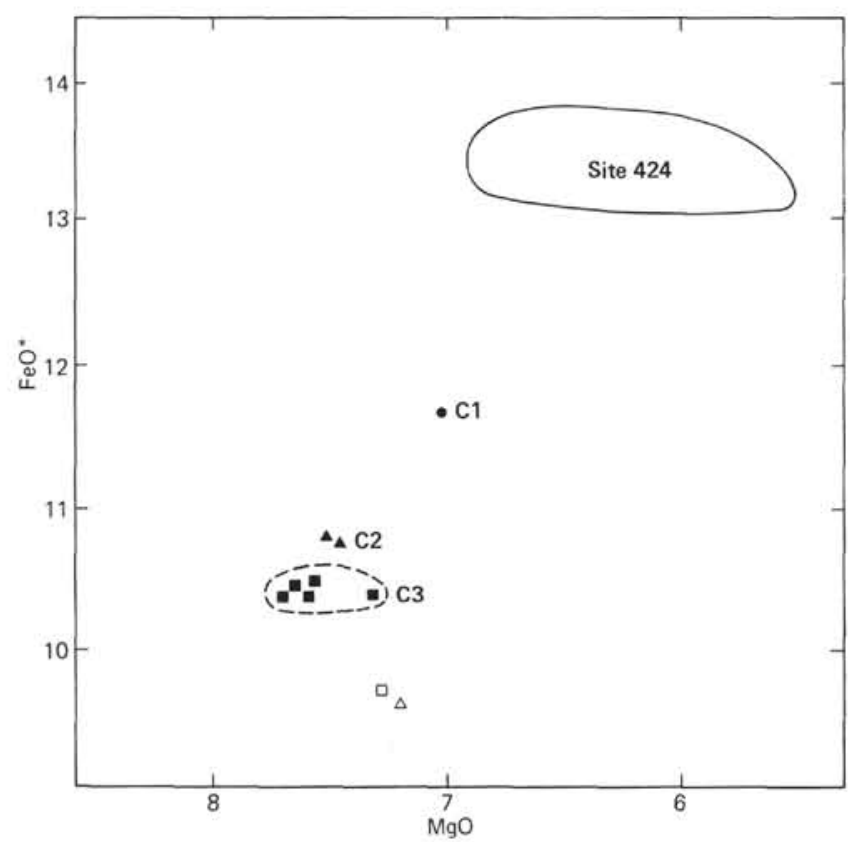

Figure 3. Plot of total iron (as $\mathrm{FeO}$ ) versus $\mathrm{MgO}$ for the basalts from Hole 425 (using full shipboard XRF data set). The three chemical units (C1, C2, and C3) are identified, and the field of Site 424 ferrobasalts is plotted for comparison. Porphyritic samples (more than $5 \%$ phenocrysts) are plotted as open symbols. (Source: Mattey and Muir, 1979).

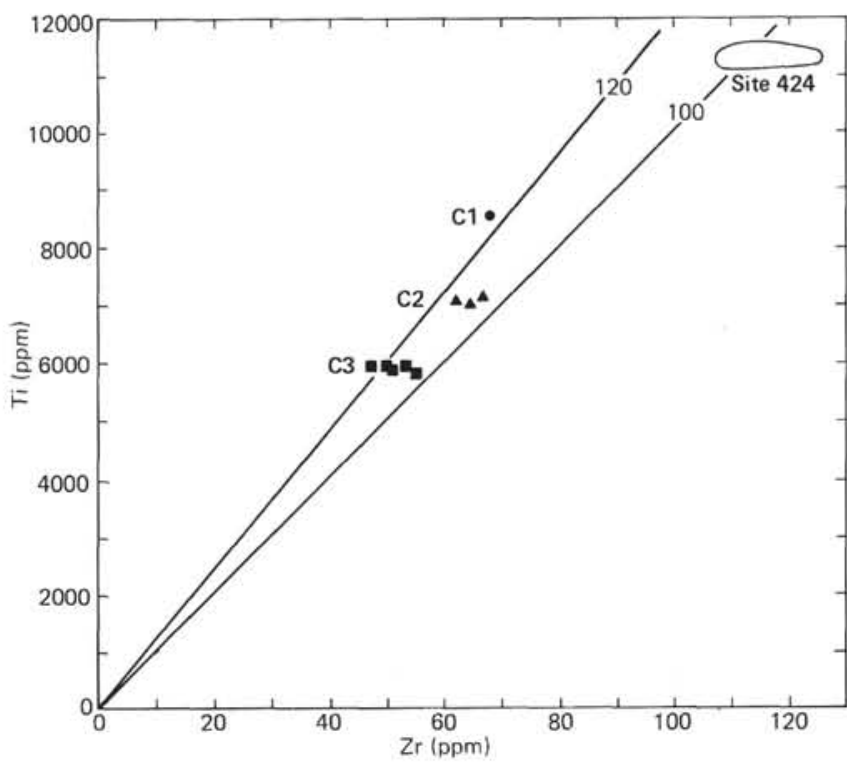

Figure 4. Plot of titanium versus zirconium for the basalts from Hole 425. Also plotted is the field of Site 424 ferrobasalts which have a slightly lower $\mathrm{Ti} / \mathrm{Zr}$ ratio. The basalts belonging to the three chemical groups from Hole 425 fall on an approximately linear fractionation trend, suggesting that both $\mathrm{Ti}$ and $\mathrm{Zr}$ are behaving as incompatible elements. (Source: Mattey and Muir, 1979).

TABLE 2

Phenocryst and Groundmass Compositions, Site 424 and Hole 425

\begin{tabular}{|c|c|c|c|c|c|}
\hline \multirow{2}{*}{$\begin{array}{c}\text { Sample } \\
\begin{array}{l}\text { [Hole-Core-Section } \\
\text { (Piece No.)] }\end{array}\end{array}$} & \multicolumn{2}{|c|}{ Plagioclase $(\% \text { An })^{\mathrm{a}}$} & \multicolumn{2}{|c|}{ Olivine $(\% \mathrm{Fo})^{\mathrm{a}}$} & \multirow{2}{*}{$\begin{array}{l}\text { Cpx } \\
\text { Pheno- } \\
\text { cryst }\end{array}$} \\
\hline & Phenocryst & $\begin{array}{c}\text { Ground- } \\
\text { mass }\end{array}$ & $\begin{array}{l}\text { Pheno- } \\
\text { cryst }\end{array}$ & $\begin{array}{l}\text { Ground- } \\
\text { mass }\end{array}$ & \\
\hline $424-5-1(13)$ & $\mathrm{tr}$ & $62(69-50)$ & - & - & - \\
\hline $5-2(26)$ & - & nd & - & - & - \\
\hline $5-4(1)$ & - & $62(67-58)$ & $73(73-74)$ & - & - \\
\hline $6-1(10 c)$ & - & $65(72-58)$ & 72 & _- & - \\
\hline $6-2(2 a)$ & - & $65(73-57)$ & - & - & - \\
\hline $6-3$ (1d) & - & $60(66-54)$ & - & - & - \\
\hline $424 B-5-1(6)$ & - & $67(68-67)$ & 76 & - & - \\
\hline $6-1(5)$ & 73 & nd & - & - & * \\
\hline $425-7-1(7)$ & 82 & $68(71-67)$ & - & - & - \\
\hline $7.2(8 b)$ & $82[c]$ & $69(78-61)$ & - & - & $*$ \\
\hline & $61[\mathrm{r}]$ & & & & \\
\hline $8-1(12)$ & $\begin{array}{l}89(91-87)[\mathrm{c}] \\
80[\mathrm{r}]\end{array}$ & nd & 85 & - & - \\
\hline $8-1(14)$ & $\begin{array}{l}91(94-88)[\mathrm{c}] \\
74[\mathrm{r}]\end{array}$ & nd & tr & - & - \\
\hline $9-3(9)$ & $84(97-84)$ & nd & - & - & - \\
\hline
\end{tabular}

Note: $[\mathrm{c}]=\operatorname{core} ;[\mathrm{r}]=\mathrm{rim}$.

$\mathrm{tr}=$ trace quantity identified.

nd $=$ no data available.

$*=$ phenocrysts present.

$-=$ phase absent.
atmean (range).

The relationship between the average phenocryst composition in each sample (see Table 2) and the $\mathrm{Fe} / \mathrm{Mg}$ ratio of the host rock is illustrated in Figure 6. The calcium content of the phenocrysts (expressed as mole $\%$ anorthite) clearly decreases with increasing fractionation of the host rock. The phenocrysts from the porphyritic basalts from Unit C2 (Lithological Unit L3) appear to be anomalously calcic and may be cumulative in origin. Flow differentiation is a likely mechanism. 

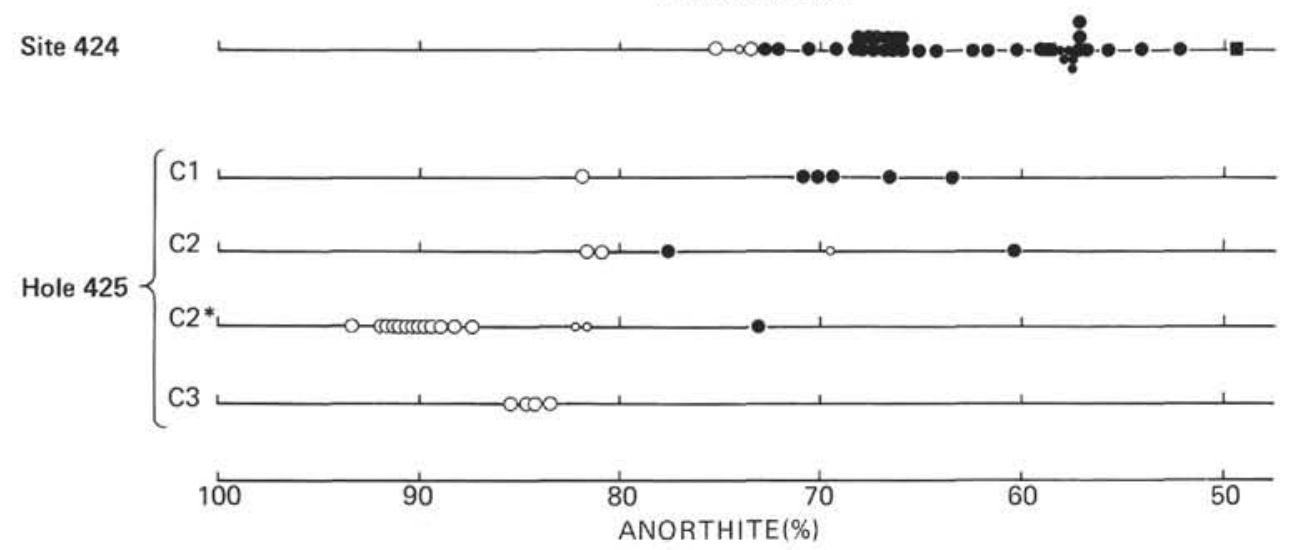

Figure 5. Summary of the variation in plagioclase composition found in the Galapagos basalts. Open symbols-(large) phenocryst cores, (small) phenocryst rims. Closed symbols-(large) groundmass cores, (small) groundmass rims. Samples belonging to different chemical units in Hole 425 are distinguished. Compositions labeled $C 2^{*}$ are from the strongly porphyritic Lithological Unit L3. (Source: Mattey and Muir, 1979.)

TABLE 3

Representative Plagioclase Analyses, Site 424 and Hole 425

\begin{tabular}{|c|c|c|c|c|c|c|c|c|}
\hline \multirow{2}{*}{$\frac{\text { Hole }}{\text { Analyses }}$} & \multicolumn{3}{|c|}{424} & \multirow{2}{*}{$\frac{424 \mathrm{~B}}{4}$} & \multicolumn{4}{|c|}{425} \\
\hline & 1 & 2 & 3 & & 5 & 6 & 7 & 8 \\
\hline Type & $g(c)$ & $g(r)$ & $\mathrm{i}(\mathrm{c})$ & $\mathrm{p}(\mathrm{c})$ & $\mathrm{p}(\mathrm{c})$ & $\mathrm{p}(\mathrm{c})$ & $\mathrm{p}(\mathrm{c})$ & $\mathrm{p}(\mathrm{c})$ \\
\hline $\mathrm{SiO}_{2}$ & 52.20 & 56.41 & 56.53 & 50.50 & 48.81 & 49.04 & 45.55 & 49.33 \\
\hline $\mathrm{Al}_{2} \mathrm{O}_{3}$ & 30.36 & 27.57 & 27.11 & 31.13 & 32.84 & 33.00 & 34.80 & 33.00 \\
\hline $\mathrm{FeO}$ & 0.66 & 1.33 & 0.67 & 0.60 & 0.47 & 0.43 & 0.38 & 0.47 \\
\hline $\mathrm{CaO}$ & 14.09 & 10.87 & 9.97 & 14.42 & 16.00 & 16.20 & 18.28 & 16.50 \\
\hline $\mathrm{Na}_{2} \mathrm{O}$ & 2.87 & 4.55 & 5.59 & 2.59 & 1.97 & 2.03 & 0.73 & 1.78 \\
\hline $\mathrm{K}_{2} \mathrm{O}$ & - & - & 0.16 & - & - & - & - & - \\
\hline Total & 100.18 & 100.70 & 100.03 & 99.19 & 100.09 & 100.70 & 99.74 & 100.08 \\
\hline \multicolumn{9}{|c|}{ Cation proportions on the basis of six oxygens } \\
\hline $\mathrm{Si}$ & 2.366 & 2.525 & 2.543 & 2.314 & 2.227 & 2.223 & 2.103 & 2.204 \\
\hline Al & 1.622 & 1.455 & 1.438 & 1.683 & 1.767 & 1.764 & 1.894 & 1.792 \\
\hline $\mathrm{Fe}$ & 0.025 & 0.050 & 0.025 & 0.023 & 0.018 & 0.016 & 0.015 & 0.015 \\
\hline $\mathrm{Ca}$ & 0.684 & 0.521 & 0.480 & 0.709 & 0.782 & 0.787 & 0.904 & 0.812 \\
\hline $\mathrm{Na}$ & 0.252 & 0.394 & 0.487 & 0.230 & 0.174 & 0.178 & 0.065 & 0.137 \\
\hline K & - & - & 0.006 & - & - & - & - & - \\
\hline Total & 4.494 & 4.945 & 4.979 & 4.959 & 4.968 & 4.968 & 4.982 & 4.960 \\
\hline$\% \mathrm{An}$ & 73.1 & 56.9 & 49.3 & 75.5 & 81.8 & 81.5 & 93.3 & 85.5 \\
\hline$\% \mathrm{Ab}$ & 26.9 & 43.1 & 50.1 & 24.5 & 18.2 & 18.5 & 6.7 & 14.5 \\
\hline$\% \mathrm{Or}$ & - & - & 0.6 & - & - & - & - & - \\
\hline
\end{tabular}

Note: $\mathrm{p}=$ phenocryst; $\mathrm{g}=$ groundmass; $\mathrm{i}=$ interstitial $($ lath $) ;(\mathrm{c})=$ core and $(\mathrm{r})=$ rim. $1=$ Core calcic groundmass crystal (Section 424-6-2, Piece 2a).

2 = Rim calcic groundmass crystal (Section 424-6-2, Piece 2a).

$3=$ Interstitial crystal (Section 424-5-1, Piece 13).

4 = Phenocryst core (Section 424B-6-1, Piece 5).

$5=$ Phenocryst core, Unit I (Section 425-7-1, Piece 7).

$6=$ Phenocryst core, Unit IIa (Section 425-7-2, Piece 8b).

$7=$ Most calcic phenocryst, porphyritic Unit IIb (Section 425-8-1, Piece 14)

8 = Phenocryst, Unit 3 (Section 425-9-3, Piece 9).

\section{Olivine}

Olivine is generally rare in all the samples studied, particularly in the basalts from Hole 425 . Where present, only very small variations in composition are observed. The results are summarized in Table 2 , and full representative analyses are given in Table 4.

Phenocryst core compositions in the Hole 424 ferrobasalts (Analyses 1 and 2, Table 4) vary from $\mathrm{Fo}_{74}$ to $\mathrm{Fo}_{72}$. Those from Hole 424B (Analysis 3, Table 4) are slightly more magnesian $\left(\mathrm{Fo}_{76}\right)$. These core composi-

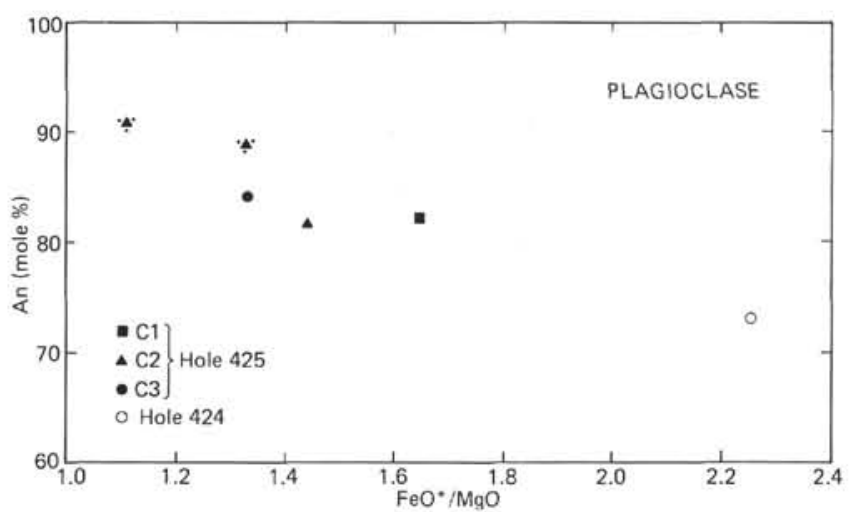

Figure 6. Plot of average phenocryst core composition (from Table 2) versus host rock $\mathrm{FeO} * / \mathrm{MgO}$ ratio for each sample studied. See text for explanation. (Source: Mattey and Muir, 1979).

tions compare closely with the theoretical olivine compositions that would crystallize in equilibrium with a liquid of the same composition of the whole rock. ${ }^{2}$ This suggests that these olivine phenocrysts are in equilibrium with the host rock. The more forsteritic olivines from Hole 424B are slightly more magnesian than the equilibrium composition and may be cumulate in origin. The $\mathrm{CaO}$ content of all olivines from Site 424 is relatively high $(\sim 0.3 \%)$, suggesting that these olivines crystalized at low pressures (Simkin and Smith, 1970).

Olivine phenocrysts fom Hole 425 are restricted to the highly porphyritic Unit L3, where they occur with the anomalously calcic plagioclase phenocrysts. These olivine phenocrysts are considerably more magnesian $\left(\mathrm{Fo}_{86}\right.$, Analysis 4, Table 4) than those found in the fer-

${ }^{2}$ Calculated using the equation of Roeder and Emslie (1970) with $\mathrm{K} \underset{01 / 1}{\mathrm{Mg} / \mathrm{Fe}}=0.33$ and $\mathrm{Fe}_{2} \mathrm{O}_{3} / \mathrm{FeO}=0.15$ (Cawthorn et al., 1975). 
TABLE 4

Representative Analyses of Olivine Phenocrysts, Site 424 and Hole 425

\begin{tabular}{|c|c|c|c|c|}
\hline \multirow{2}{*}{$\frac{\text { Hole }}{\text { Analysis }}$} & \multicolumn{2}{|c|}{424} & \multirow{2}{*}{$\frac{424 \mathrm{~B}}{3}$} & \multirow{2}{*}{$\frac{425}{4}$} \\
\hline & 1 & 2 & & \\
\hline $\mathrm{SiO}_{2}$ & 38.12 & 38.37 & 38.87 & 39.91 \\
\hline $\mathrm{FeO}$ & 23.47 & 24.38 & 21.68 & 13.10 \\
\hline $\mathrm{MnO}$ & 0.27 & 0.28 & 0.21 & 0.19 \\
\hline $\mathrm{MgO}$ & 37.41 & 36.63 & 38.72 & 45.65 \\
\hline $\mathrm{CaO}$ & 0.29 & 0.24 & 0.36 & 0.33 \\
\hline $\mathrm{CoO}$ & 0.35 & 0.32 & 0.24 & 0.26 \\
\hline $\mathrm{NiO}$ & 0.15 & - & 0.15 & 0.21 \\
\hline Total & 100.05 & 100.22 & 100.28 & 99.65 \\
\hline \multicolumn{5}{|c|}{ Cation proportions (four oxygens) } \\
\hline $\mathrm{Si}$ & 0.999 & 1.00 & 1.003 & 0.998 \\
\hline $\mathrm{Fe}$ & 0.515 & 0.5 & 0.470 & 0.273 \\
\hline $\mathrm{Mn}$ & 0.006 & 0.006 & 0.005 & 0.00 \\
\hline $\mathrm{Mg}$ & 1.462 & 1.4 & 1.50 & 1.70 \\
\hline $\mathrm{Ca}$ & 0.00 & 0.0 & 0.010 & 0.0 \\
\hline Co & 0.00 & 0.007 & 0.0 & $0.0 \mathrm{C}$ \\
\hline $\mathrm{Ni}$ & 0.003 & - & 0.003 & 0.004 \\
\hline Total & 3.000 & 2.993 & 2.997 & 3.00 \\
\hline$\% \mathrm{Fe}$ & 74.0 & 72.8 & 75.8 & 86.2 \\
\hline
\end{tabular}

Note:

$1=$ Most Mg-rich olivine, Hole 424 [Section 424-5-4 (Piece 1)].

$2=$ Least $\mathrm{Mg}$-rich olivine, same sample as Analysis 1.

$3=$ Phenocryst, Hole 424B [Section 424B-5-1 (Piece 6)].

4 = Phenocryst Hole 425, Unit C2 (L3). [Section 425-8-1 (Piece 12)].

robasalts. Nevertheless, these phenocrysts are slightly more magnesian than the theoretical equilibrium olivine composition $\left(\sim \mathrm{Fo}_{80}\right)$, suggesting that they may also be cumulative in origin.

\section{Clinopyroxene}

\section{Phenocrysts}

Clinopyroxene phenocrysts are occasionally found in the Site 424 ferrobasalts and in Units L2, L4, and L5 in Hole 425. When present they are not abundant, and usually only two or three crystals per thin section are observed. The compositional ranges found at each site are illustrated in Figures 7 and 8, and representative analyses are presented in Table 5 .

The main compositional variation in phenocrysts from both the basalts (Hole 425) and ferrobasalts (Site 424 ) is in calcium content at a relatively constant $\mathrm{Fe} / \mathrm{Mg}$ ratio. Much of the variation is caused by patchy concentric zoning, resulting in the rims of most crystals being less calcic and usually poorer in $\mathrm{Al}_{2} \mathrm{O}_{3}$ and $\mathrm{Cr}_{2} \mathrm{O}_{3}$ (e.g., Analyses 1, 2, and 5, 6, Table 5).

There are significant differences in overall composition between the phenocrysts from Site 424 and Hole 425. Phenocrysts from the basalts (Analyses 4-6, Table 6) are typically $\mathrm{Mg}$ - and $\mathrm{Ca}$-rich augites (Figure 8), rich in $\mathrm{Cr}_{2} \mathrm{O}_{3}\left(0.4\right.$ to over $1 \%$ ), and relatively poor in $\mathrm{TiO}_{2}$
$(0.2-0.4 \%)$. The $\mathrm{Mg}$ ratio, $100 \mathrm{Mg} /(\mathrm{Mg}+\mathrm{Fe})$, of these phenocrysts varies from 86 to 83 . Phenocrysts from the ferrobasalts (Hole 424B) (Analyses 1-3, Table 5) are less magnesian augites (Figure 7) with a typical $\mathrm{Mg}$ ratio of 78; they are poorer in $\mathrm{Cr}_{2} \mathrm{O}_{3}$, which is less than 0.3 per cent in most samples. These phenocrysts have slightly higher contents of $\mathrm{TiO}_{2}$ and $\mathrm{Na}_{2} \mathrm{O}$.

The $\mathrm{Fe}^{+3}$ content of pyroxene may be roughly estimated from the following charge balance equation (Papike et al., 1974):

$$
\mathrm{Fe}^{+3}=\mathrm{Al}^{\mathrm{IV}}-\left(\mathrm{Al}^{\mathrm{VI}}+\mathrm{Cr}^{+3}+2 \mathrm{Ti}^{+4}\right)+\mathrm{Na}^{+2}
$$

Assuming perfect stoichiometry, an excess cation charge (i.e., the sum of cations on the basis of six oxygens being greater than 4.000 ) provides a rough estimate of the ferric iron content of the pyroxene (Mysen and Heier, 1972; Cawthorn and Collerson, 1974). Many pyroxenes from the Site 424 ferrobasalts (including phenocrysts, Analyses 1 and 2, Table 5) have small cation charge excesses, suggesting slightly higher $\mathrm{Fe}_{2} \mathrm{O}_{3}$ contents of the pyroxenes from these iron-rich basalts.

\section{Groundmass}

Clinopyroxene, along with plagioclase, is a dominant groundmass phase in the Galapagos basalts and ferrobasalts. In contrast to the phenocrysts, groundmass pyroxenes in basalts from both sites display a considerable range in composition (Figures 7 and 8). The general differences between pyroxene phenocrysts from the Hole 425 basalts and the Site 424 ferrobasalts also apply to the groundmass crystals: those from the ferrobasalts are richer in $\mathrm{FeO}, \mathrm{TiO}_{2}, \mathrm{Al}_{2} \mathrm{O}_{3}, \mathrm{MnO}, \mathrm{CoO}, \mathrm{Na}_{2} \mathrm{O}$ and poorer in $\mathrm{Cr}_{2} \mathrm{O}_{3}$. Slight cation charge excess in the ferrobasalt pyroxenes suggests a larger content of $\mathrm{Fe}_{2} \mathrm{O}_{3}$.

Groundmass pyroxene analyses from Hole 425 are plotted in the pyroxene quadrilateral in Figure 8. Representative analyses are presented in Table 5 (Analyses 11-14). No differences can be detected in the pyroxenes crystallizing from each chemical unit. Most of the analyses point to magnesian augites with a moderate range of $\mathrm{Mg}$ ratios, varying from 82 to 60 . Ferro-augites are rare. Calcium (expressed in terms of percentage wollastonite) varies considerably, from $\mathrm{Wo}_{44}$ to $\mathrm{Wo}_{12}$, and the data display a strong trend toward subcalcic augite (Figure 8).

The analyses of groundmass pyroxenes from Hole 424 are plotted in Figure 7; representative analyses are given also in Table 5 (Analyses 7-10). These data show a greater range in $\mathrm{Mg}$ ratio, which varies from 75 to 40 . Calcium varies to a lesser extent, and most of the analyses fall in the range $\mathrm{Wo}_{40}$ to $\mathrm{Wo}_{30}$. Thus the groundmass pyroxene from the Site 424 ferrobasalts are characterized by a crystallization trend at a relatively constant $\mathrm{Ca}$ content through $\mathrm{Fe}$-rich augite to ferro-augite.

Although the two general crystallization paths characterizing groundmass pyroxenes from each site are well defined, there are clearly exceptions to the rule in that ferro-augite, although rare, is found in the Hole 425 basalts (Figure 8 ) and that subcalcic augite compositions are present in the Site 424 ferrobasalts. The dif- 


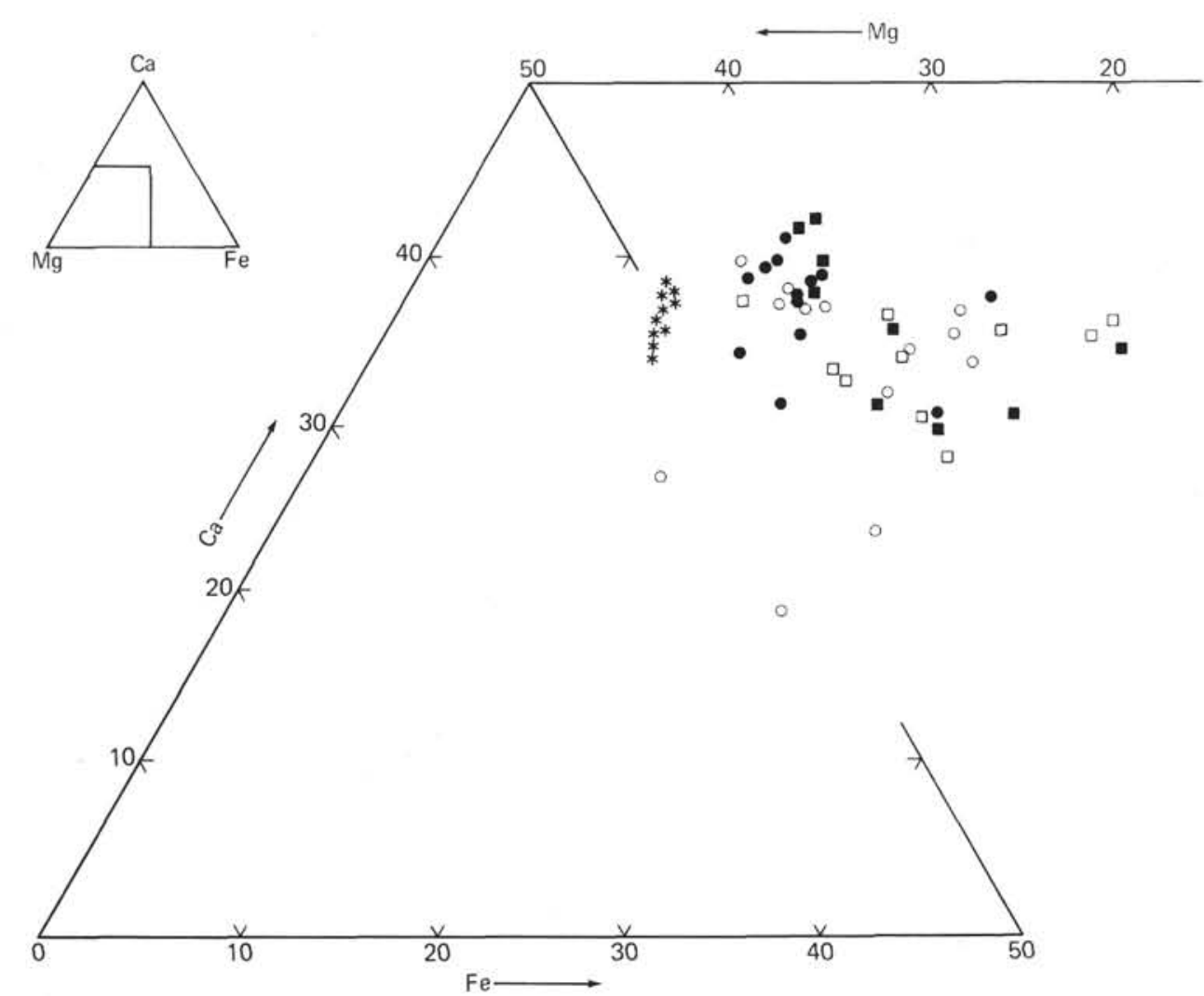

Figure 7. Phenocryst and groundmass pyroxenes from Site 424 ferrobasalts plotted in part of the pyroxene quadrilateral. Stars - phenocrysts from Section 424B-6-1 (Piece 3); closed circles - groundmass of Section 424-5-1 (Piece 13); closed squares - groundmass of Section 424-5-4 (Piece 1); open squares - groundmass of Section 424-6-2 (Piece 2a); open circles - groundmass of Section 424-6-3 (Piece 1d). (Source: Mattey and Muir, 1979).

ferent initial magma compositions at each site would appear to control the starting point of the crystallization path, but the subsequent compositional trend is probably governed by other physical factors during the crystallization of the basalt.

The crystallization path of Ca-rich pyroxene is controlled by a number of chemical and physical factors which include temperature and degree of undercooling of the host melt, volatiles, $p \mathrm{O}_{2}$, and cotectic crystallization of other phases (Barberi et al., 1971). The influence of cooling rate or degree of undercooling on the composition of pyroxene has been reported by many authors (e.g., Donaldson et al., 1975; Lofgren et al., 1974; Coish and Taylor, 1979). High degrees of undercooling promote rapid metastable crystallization of pyroxenes which become strongly subcalcic (e.g., Muir and Tilley, 1964; Smith and Lindsley, 1971; Yamakawa, 1971).

Textural evidence as to the rate of cooling of these basalts suggests that generally the Site 424 ferrobasalts may have cooled more rapidly than those from Hole 425. The former are characterized by extremely rapid changes in texture within the same thin section, from coarse ophitic intergrowths of clinopyroxene and plagioclase to large areas of glass containing granular pyroxene or feathery, skeletal clots of plagioclase and clinopyroxene. In contrast, the basalts from Hole 425 are relatively holocrystalline and are characterized by a more even grain size having typically ophitic or intergranular textures, indicative of slower cooling rates. Several units from this hole may even be sills rather than lavas. So, from textural evidence, the rock samples characterized by a dominantly subcalcic pyroxene crystallization trend (i.e., from Hole 425) would have appeared to have cooled less rapidly than Hole 425 ferrobasalts containing clinopyroxenes following a more "'equilibrium" trend of iron enrichment.

Subcalcic pyroxenes from the glassy selvages of pillow basalts and spilites (Mevel and Velde, 1976) from the chilled margins of dykes (Mattey, 1979), sills (Yamakawa, 1971; Coish and Taylor, 1979), and lavas (Fodor et al., 1975) are characteristically enriched in $\mathrm{TiO}_{2}$ and $\mathrm{Al}_{2} \mathrm{O}_{3}$ relative to calcic pyroxenes which have crystallized more slowly in the interiors of these bodies. The contents of $\mathrm{TiO}_{2}$ and $\mathrm{Al}_{2} \mathrm{O}_{3}$ in Hole 425 subcalcic augites, however, are generally lower than in the calcium-rich counterparts in the same sample (e.g., compare Analyses 7 and 10 or 11 and 14, Table 5). These lines of evidence suggest that, in this case, variations in cooling rate are not directly responsible for the different pyroxene crystallization paths.

A ferrobasalt from Site 424 with the extreme variations in texture as described here was studied in more 


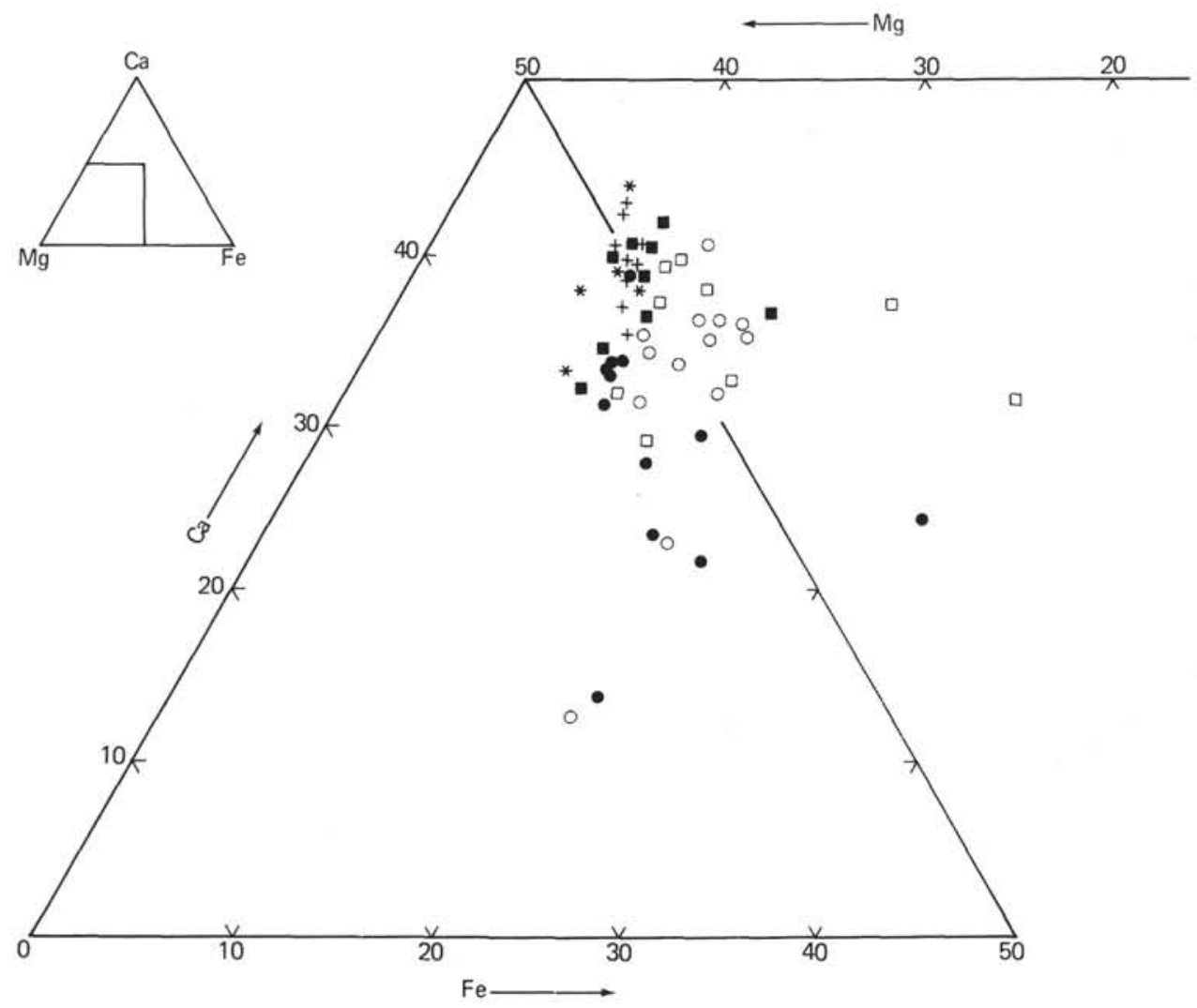

Figure 8. Phenocryst and groundmass pyroxene from Hole 425 basalts. Stars phenocrysts from Section 425-8-1 (Piece 12); crosses - groundmass from Section 425-8-1 (Piece 12); open circles - groundmass from Section 425-7-1 (Piece 7); open squares - groundmass from Section 425-7-2 (Piece 8b); closed squares groundmass from Section 425-8-1 (Piece 14); closed circles - groundmass from Section 425-9-3 (Piece 9). (Source: Mattey and Muir, 1979).

detail. The groundmass pyroxene in this sample was of two types:

1) Ophitic clinopyroxene. This was intergrown with plagioclase, forming relatively coarsely crystalline clots surrounded by glassy mesostasis (approximately equal areas of crystalline and glassy material). This pyroxene forms optically continuous plates up to $1 \mathrm{~mm}$ in length.

2) Granular pyroxene. These small anhedral grains float in large patches of glassy mesostasis which also contain granular or skeletohedral titanomagnetite and microlites of skeletal plagioclase. Some of these "glassy" pyroxenes have a larger (up to $0.5 \mathrm{~mm}$ ) feathery morphology, some with simple twinning; they show patchy or undulose extinction.

Sixty analyses including both types of clinopyroxene are plotted in Figures 9 and 10. Representative analyses are given in Table 6 . The range of compositions found in this single sample is equivalent to the combined variation of all the Galapagos pyroxenes analyzed in this study. The analyses of the ophitic and glassy pyroxenes clearly fall into two groups when plotted in the pyroxene quadrilateral (Figure 9).

The ophitic pyroxenes (Figure 9) with a small range of $\mathrm{Mg}$ ratios (75-68) are similar to those found in the dominantly ophitic or intergranular Hole 425 basalts, and become rapidly depleted in calcium (from $\mathrm{Wo}_{40}$ to $\mathrm{Wo}_{20}$; Analyses 1-4, Table 6). These optically continuous plates of clinopyroxene become more subcalcic close to plagioclase laths.

The behavior of $\mathrm{Ca}$ and the minor elements (recalculated to six oxygens) relative to the $\mathrm{Mg}$ ratio is illustrated in Figure 10. For all the pyroxenes, elements such as $\mathrm{Cr}, \mathrm{Mn}, \mathrm{Co}$, and V form a coherent trend. The behavior of $\mathrm{Al}$ and $\mathrm{Ti}$, however, is more complex. It can be seen that both $\mathrm{Al}$ and $\mathrm{Ti}$ in the ophitic pyroxenes initially rise and reach a maximum at an $\mathrm{Mg}$ ratio of $\sim 73$. As the $\mathrm{Mg}$ ratio continues to fall and the pyroxene begins to become subcalcic, $\mathrm{Al}$ and $\mathrm{Ti}$ also fall resulting in low $\mathrm{Al}$ and $\mathrm{Ti}$ contents in the most subcalcic compositions.

The granular pyroxenes found in the glassy mesostasis (Analyses 6-9, Table 6) are more typical of the greater number of pyroxenes found in the Site 424 ferrobasalts. With a wide range of $\mathrm{Mg}$ ratios (65-40), there is a relatively small variation in calcium (Figure 9). Ti and $\mathrm{Al}$ contents in the "glassy" pyroxenes are higher than in the ophitic examples (Figure 10) and increase with falling $\mathrm{Mg}$ ratio. It is perhaps significant that the only subcalcic ferroaugite (Analysis 9, Table 6) found in the glassy mesostasis is significantly poorer in $\mathrm{Al}$ and 
TABLE 5

Representative Clinopyroxene Analyses, Site 424 and Hole 425

\begin{tabular}{|c|c|c|c|c|c|c|c|c|c|c|c|c|c|c|}
\hline \multirow{2}{*}{$\frac{\text { Hole }}{\text { Analysis }}$} & \multicolumn{3}{|c|}{$424 B$} & \multicolumn{3}{|c|}{425} & \multicolumn{4}{|c|}{424} & \multicolumn{4}{|c|}{425} \\
\hline & 1 & 2 & 3 & 4 & 5 & 6 & 7 & 8 & 9 & 10 & 11 & 12 & 13 & 14 \\
\hline Type & $\mathrm{p}(\mathrm{c})$ & $\mathrm{p}(\mathrm{r})$ & $\mathrm{p}$ & $\mathrm{p}(\mathrm{c})$ & $\mathrm{p}(\mathrm{c})$ & $\mathrm{p}(\mathrm{r})$ & $\mathrm{g}$ & $\mathrm{g}$ & $\mathrm{g}$ & $\mathrm{g}$ & $\mathrm{g}$ & $\mathrm{g}$ & $\mathrm{g}$ & $\mathrm{g}$ \\
\hline $\mathrm{SiO}_{2}$ & 52.43 & 52.62 & 53.07 & 52.78 & 54.59 & 54.63 & 49.45 & 50.18 & 49.44 & 52.19 & 52.22 & 52.68 & 50.27 & 55.30 \\
\hline $\mathrm{TiO}_{2}$ & 0.41 & 0.35 & 0.46 & 0.372 & 0.25 & 0.26 & 1.46 & 1.22 & 1.00 & 0.58 & 0.44 & 0.52 & 0.73 & 0.20 \\
\hline $\mathrm{Al}_{2} \mathrm{O}_{3}$ & 2.15 & 1.57 & 2.06 & 3.05 & 1.66 & 1.43 & 4.16 & 1.93 & 1.45 & 1.47 & 3.16 & 2.29 & 1.42 & 1.19 \\
\hline $\mathrm{Cr}_{2} \mathrm{O}_{3}$ & 0.28 & 0.25 & 0.27 & 1.18 & 0.55 & 0.45 & 0.18 & 0.11 & - & 0.14 & 0.27 & - & 0.13 & - \\
\hline $\mathrm{FeO}$ & 8.32 & 8.61 & 8.29 & 5.126 & 6.71 & 7.37 & 11.07 & 17.68 & 22.78 & 17.92 & 7.06 & 10.39 & 20.99 & 13.60 \\
\hline $\mathrm{MnO}$ & 0.17 & 0.15 & 0.10 & - & 0.20 & 0.19 & 0.15 & 0.35 & 0.54 & 0.28 & 0.22 & 0.14 & 0.42 & 0.31 \\
\hline $\mathrm{MgO}$ & 17.05 & 17.95 & 17.44 & 16.66 & 20.34 & 20.72 & 13.42 & 12.23 & 9.18 & 18.20 & 16.36 & 16.95 & 11.45 & 23.97 \\
\hline $\mathrm{CaO}$ & 18.47 & 16.79 & 18.30 & 21.20 & 16.33 & 15.21 & 19.67 & 16.60 & 15.74 & 8.83 & 20.07 & 17.08 & 14.53 & 6.17 \\
\hline $\mathrm{CoO}$ & - & - & - & 0.133 & - & - & 0.16 & 0.28 & 0.24 & 0.27 & - & 0.14 & 0.27 & 0.15 \\
\hline $\mathrm{Na}_{2} \mathrm{O}$ & 0.49 & 0.39 & - & - & - & - & 0.46 & - & - & - & - & - & - & - \\
\hline $\mathrm{V}_{2} \mathrm{O}_{5}$ & - & - & - & - & 0.15 & - & 0.16 & - & - & - . & - & 0.14 & - & - \\
\hline \multirow[t]{2}{*}{ Total } & 99.79 & 98.68 & 99.98 & 100.51 & 100.78 & 100.26 & 100.32 & 100.58 & 100.37 & 99.88 & 99.80 & 100.33 & 100.21 & 100.89 \\
\hline & \multicolumn{10}{|c|}{ Cation proportions on the basis of six oxygens } & & & & \\
\hline $\mathrm{Si}$ & 1.937 & 1.958 & 1.948 & 1.921 & 1.962 & 1.972 & 1.856 & 1.916 & 1.936 & 1.956 & 1.922 & 1.941 & 1.945 & 1.985 \\
\hline $\mathrm{AlI}^{\mathrm{IV}}$ & 0.063 & 0.042 & 0.052 & 0.079 & 0.038 & 0.028 & 0.144 & 0.084 & 0.064 & 0.044 & 0.078 & 0.059 & 0.055 & 0.015 \\
\hline $\mathrm{Al}^{\mathrm{VI}}$ & 0.031 & 0.027 & 0.038 & 0.052 & 0.032 & 0.033 & 0.040 & 0.003 & 0.003 & 0.021 & 0.059 & 0.040 & 0.010 & 0.036 \\
\hline $\mathrm{Ti}$ & 0.011 & 0.010 & 0.013 & 0.010 & 0.007 & 0.007 & 0.041 & 0.035 & 0.030 & 0.016 & 0.012 & 0.014 & 0.021 & 0.006 \\
\hline $\mathrm{Cr}$ & 0.008 & 0.007 & 0.008 & 0.034 & 0.016 & 0.013 & 0.005 & 0.003 & - & 0.004 & 0.008 & - & 0.004 & - \\
\hline $\mathrm{Fe}^{+2}$ & 0.257 & 0.268 & 0.255 & 0.156 & 0.202 & 0.222 & 0.347 & 0.567 & 0.746 & 0.562 & 0.217 & 0.320 & 0.679 & 0.408 \\
\hline $\mathrm{Mn}$ & 0.005 & 0.005 & 0.003 & - & 0.006 & 0.006 & 0.005 & 0.011 & 0.018 & 0.009 & 0.007 & 0.005 & 0.014 & 0.009 \\
\hline $\mathrm{Mg}$ & 0.939 & 0.996 & 0.954 & 0.903 & 1.089 & 1.115 & 0.750 & 0.696 & 0.536 & 1.017 & 0.897 & 0.931 & 0.661 & 1.283 \\
\hline $\mathrm{Ca}$ & 0.731 & 0.669 & 0.720 & 0.827 & 0.629 & 0.588 & 0.791 & 0.679 & 0.660 & 0.355 & 0.791 & 0.674 & 0.602 & 0.238 \\
\hline $\mathrm{Co}$ & - & - & - & 0.004 & - & - & 0.005 & 0.008 & 0.008 & 0.008 & - & 0.004 & 0.008 & 0.004 \\
\hline $\mathrm{Na}$ & 0.035 & 0.028 & - & - & - & - & 0.033 & - & - & - & - & - & - & - \\
\hline V & - & - & - & - & 0.004 & - & 0.005 & - & - & - & - & 0.004 & - & - \\
\hline$X$ & 2.000 & 2.000 & 2.000 & 2.000 & 2.000 & 2.000 & 2.000 & 2.000 & 2.000 & 2.000 & 2.000 & 2.000 & 2.000 & 2.000 \\
\hline $\mathrm{Y}$ & 1.252 & 1.312 & 1.271 & 1.159 & 1.357 & 1.396 & 1.199 & 1.324 & 1.341 & 1.638 & 1.202 & 1.319 & 1.391 & 1.746 \\
\hline Z & 0.766 & 0.697 & 0.720 & 0.827 & 0.629 & 0.588 & 0.824 & 0.679 & 0.660 & 0.355 & 0.791 & 0.674 & 0.602 & 0.238 \\
\hline $\mathrm{XYZ}$ & 4.018 & 4.009 & 3.991 & 3.986 & 3.986 & 3.984 & 4.023 & 4.003 & 4.001 & 3.993 & 3.993 & 3.993 & 3.999 & 3.984 \\
\hline $\mathrm{Mg} /(\mathrm{Mg}+\mathrm{Fe})$ & 78.5 & 78.8 & 78.9 & 85.3 & 84.4 & 83.4 & 68.3 & 55.0 & 41.8 & 64.4 & 80.5 & 74.4 & 49.3 & 75.9 \\
\hline $\mathrm{Ca}$ & 37.9 & 34.6 & 37.3 & 43.8 & 32.8 & 30.6 & 41.9 & 34.9 & 34.00 & 18.3 & 41.5 & 35.0 & 31.1 & 12.3 \\
\hline $\mathrm{Mg}$ & 48.7 & 51.5 & 49.5 & 47.9 & 56.8 & 57.9 & 39.7 & 35.8 & 27.6 & 52.6 & 47.1 & 48.3 & 34.0 & 66.5 \\
\hline $\mathrm{Fe}$ & 13.4 & 13.9 & 13.2 & 8.3 & 10.4 & 11.6 & 18.4 & 29.3 & 28.4 & 29.1 & 11.4 & 16.7 & 34.9 & 21.2 \\
\hline
\end{tabular}

Notes:

$1=$ Core, Mg-augite (phenocryst 1, Section 424B-6-1 (Piece 3).

$2=$ Rim, as a bove.

$3=$ Average analyses ( 13 points) (phenocryst 2 , as above).

4 = Core, endiopside (phenocryst 1, Section 425-8-1 (Piece 12).

$5=$ Core, Mg-augite (phenocryst 2, same as Analysis 4).

$6=\mathrm{Rim}$, as for 5 .

$7=\mathrm{Mg}, \mathrm{Ca}$-rich ophitic augite [Section 424-5-4 (Piece 1)].

$8=$ Less Mg-rich ophitic augite [Section 424-6-3 (Piece 1d)] .

$9=$ Ferro-augite in glass mesostasis (same as Analysis 7).

$10=$ Subcalcic ophitic augite (same as Analysis 8).

$11=\mathrm{Mg}, \mathrm{Ca}-\mathrm{rich}$ ophitic augite [Section 425-8-1 (Piece 14)] .

12 = Less Mg-rich ophitic augite (same as Analysis 11).

13 = Ferro-augite in glass mesostasis [Section 425-7-2 (Piece 86)].

14 = Mg-pigeonite (ophitic) [Section 425-7-1 (Piece 7)] .

Ti (Figure 10b). It formed a small glomerophyric clot with skeletal plagioclase, suggesting that the cotectic crystallization of pyroxene with plagioclase results in the formation of Al-poor, subcalcic augite.

Thus, within one thin section the variations in groundmass pyroxene composition are almost equivalent to the entire range of variation observed in the Galapagos basalts. Compositions ranging from $\mathrm{Mg}, \mathrm{Ca}-$ rich augite to subcalcic augite and pigeonite characterize the relatively coarse grained ophitic pyroxenes, whereas granular pyroxenes from the glassy mesostasis are typically Fe-rich augites or ferro-augites. The broad textural differences between the Hole 425 basalts (relatively coarse grained, ophitic, or intergranular) and the Site 424 ferrobasalts (glass-rich, more abundant quench tex- tures, finer grain size, etc.) may account for the different crystallization paths characterizing the groundmass pyroxenes from each site. The formation of strongly subcalcic augites seems to result from cotectic crystallization with plagioclase, rather than from rapid metastable crystallization caused by quenching.

\section{DISCUSSION}

Recently, much attention has been focused (e.g., Tarney et al., 1979, and in press) on the range of MORB compositions erupted along spreading ridges, using elements that reflect the nature of the mantle source rather than those that are affected by shallow crystal fractionation, and it is necessary to qualify the term "normal" MORB. Sun et al., (1979) have classified 


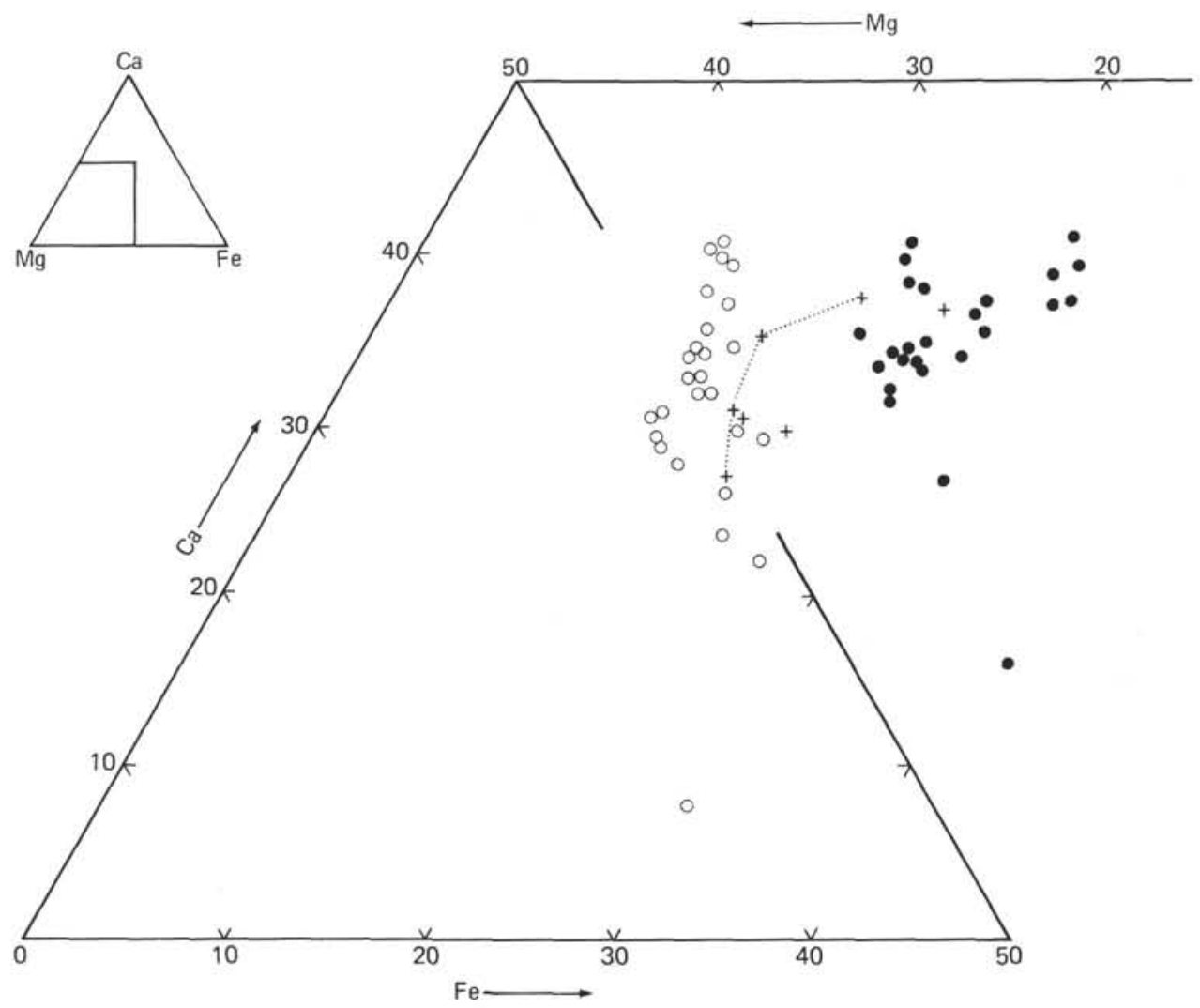

Figure 9. Groundmass pyroxenes from Section 424-6-1 (Piece 10c). Open circles ophitic pyroxene intergrown with plagioclase; closed circles - granular pyroxene from glassy mesostasis; crosses - larger feathery pyroxene extending from ophitic clots into glassy mesostasis. Dotted line links analyses from the same crystal and indicates how such crystals become rich in iron and calcium as they enter glassy areas. (Source: Mattey and Muir, 1979).

MORB according to abundances and ratios of incompatible elements and of radiogenic to non-radiogenic isotopes into three groups: "normal," or N-type, "enriched," or E-type, and "transitional" or T-type. Examples of these three types of basalt are given in Table 7.

$\mathrm{N}$-type MORB is most abundant and is found, for example, along the Mid-Atlantic Ridge at $22^{\circ} \mathrm{N}$ (Bougault et al., 1979). It is characterized by very low abundances of the incompatible elements and by strongly light-REdepleted REE patterns (Analysis 12, Table 7). E-type MORB is erupted at ocean islands (i.e., hot-spot areas) and is enriched in incompatible elements relative to $\mathrm{N}$-type MORB with light-RE-enriched REE patterns (Analyis 14, Table 7). T-type MORB is transitional between both these types (e.g., Analysis 13, Table 7).

The basalts recovered from the Galapagos Spreading Center at $86^{\circ} \mathrm{W}$, although characterized by moderate to strong iron enrichment, are nevertheless fundamentally similar to most $\mathrm{N}$-type mid-oceanic ridge basalts, with respect to, for example, abundances of $\mathrm{K}, \mathrm{Rb}, \mathrm{Sr}$, and REE.

Joron et al. (this volume) report $\mathrm{La} / \mathrm{Ta}$ and $\mathrm{Y} / \mathrm{La}$ ratios also characteristic of N-type MORB. It is interesting to compare the Site 424 ferrobasalts with an E-type ferrobasalt from Iceland (Analysis 14, Table 7) and note the considerable differences in abundance of elements such as $\mathrm{TiO}_{2}, \mathrm{P}_{2} \mathrm{O}_{5}, \mathrm{~K}_{2} \mathrm{O}, \mathrm{Zr}$, Hf, and REE.

The more fractionated nature of the Galapagos basalts is a feature typical of many other basalts from the East Pacific area. Ferrobasalts similar to those from Site 424 have also been dredged from the Galapagos Rift (Anderson et al., 1975; Schilling et al., 1976), from the Juan de Fuca Ridge (Dietrick and Lynn, 1975), and drilled on the Nazca plate (DSDP Leg 34, Bunch and Laborde, 1976; Kempe, 1976) and on the East Pacific Rise in the Siqueiros area (DSDP Sites 420-423, 427429; this volume). Examples of the least and most evolved basalts from these areas are given in Table 7.

Several authors (e.g., Kay et al., 1970; Batiza et al., 1977; Clague and Bunch, 1976) have suggested that extensive low-pressure crystal fractionation from a normal (i.e., N-type) MORB parent would form the ferrobasalts that characterize East Pacific fast-spreading ridges. Both Clague and Bunch (1976) and Batiza et al. (1977), using computer least-squares mixing programs, or simply by graphical extraction methods, suggest that ferrobasalts with $\mathrm{FeO} / \mathrm{MgO}$ ratios in the range of 2 to 3 are products of 70 to 80 per cent fractionation of a parental magma with $\mathrm{FeO} / \mathrm{MgO}=0.9$ to 1.2. Clague and Bunch (1976) particularly stressed the importance of clinopyroxene in the fractionating assemblage. 

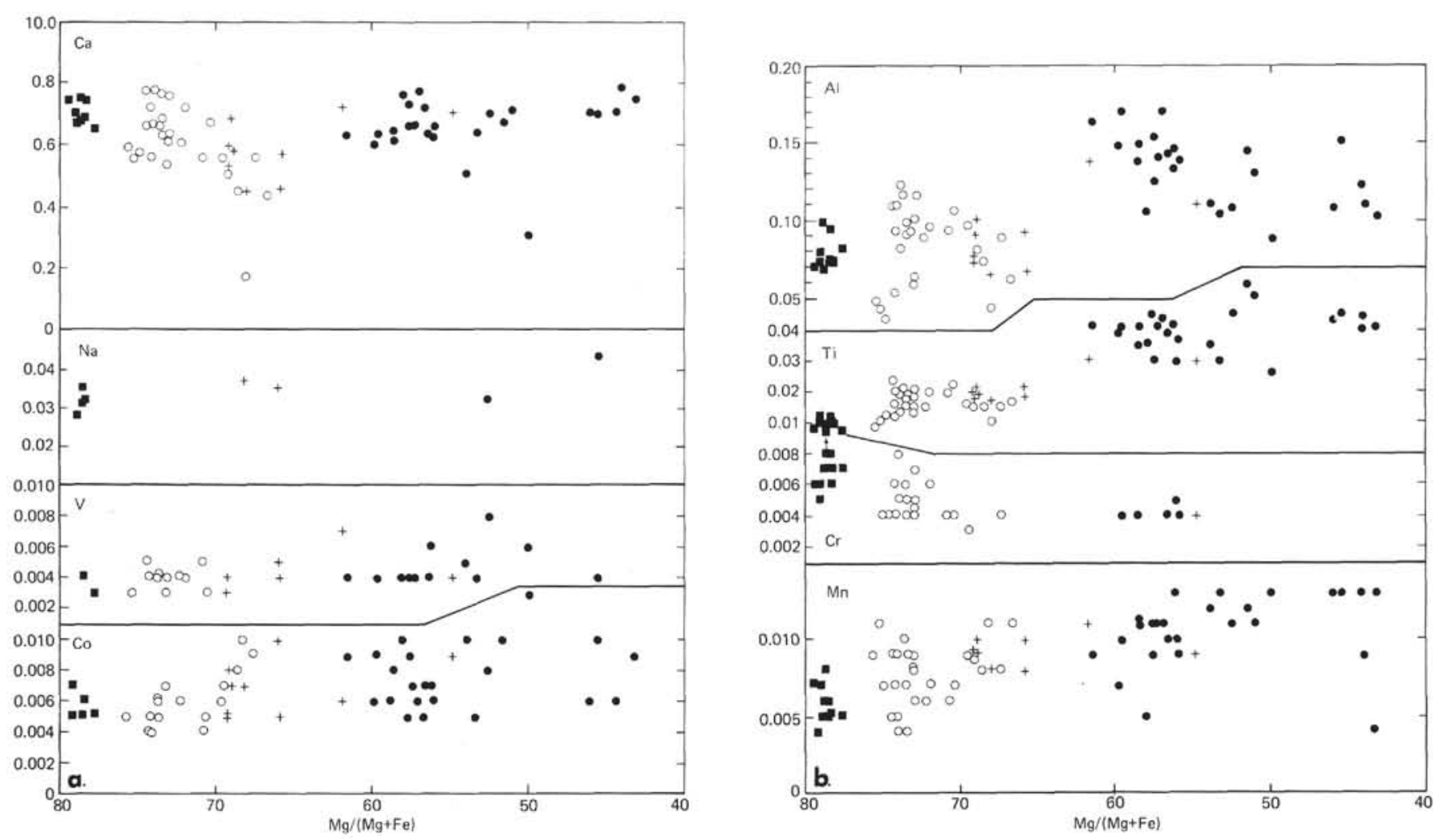

Figure 10. (A) Ca, Na, $V$, and $\mathrm{Co}$ and (B) $\mathrm{Al}, \mathrm{Ti}, \mathrm{Cr}$, and $\mathrm{Mn}$ plotted versus $\mathrm{Mg} /(\mathrm{Mg}+\mathrm{Fe})$ for the pyroxene in Figure 9. Also plotted for comparison are phenocrysts from Section 424B-6-1 (Piece 5). Same symbols as Figure 9. (Source: Mattey and Muir, 1979).

The least-squares petrological mixing program of Wright and Doherty (1970) was used to test whether, in Hole 425, the more evolved units $\mathrm{C} 1$ and $\mathrm{C} 2$ could be derived from a parental Unit C3 by low-pressure crystal fractionation. For these calculations, the average composition of the aphyric or sparsely phyric basalts was taken from the complete XRF shipboard data set and used with suitable phenocrysts compositions selected from the microprobe data. The results of these calculations are set out in Table 8 . The residuals for most elements are low, and the mixes are considered fairly satisfactory. The results suggest that Unit $\mathrm{C} 1$ may be derived from a parental Unit C 3 by 16 per cent fractional crystallization of an assemblage consisting of 54 per cent clinopyroxene, 44 per cent plagioclase, and 2 per cent olivine. The proportions of the fractionating phases are remarkably similar to the results obtained by Clague and Bunch (1976) - that is, 47 per cent clinopyroxene, 46 per cent plagioclase, and 7 per cent olivine.

This fractionation model was extended to the behavior of the minor and trace elements $\mathrm{Ti}, \mathrm{Zr}, \mathrm{Ni}, \mathrm{Sr}$, $\mathrm{Ce}, \mathrm{Eu}, \mathrm{Yb}$, and $\mathrm{Hf}$ using the Rayleigh equilibrium fractionation equation (see Table 10). For each element a bulk-distribution coefficient was calculated using the phase proportions predicted by the least-squares mixing calculations. The distribution coefficients used in the calculations are listed in Table 9. The degree of fractionation required to account for the observed change in concentration of each element from Unit C3 to $\mathrm{C} 1$ was calculated. These results are presented in Table 10, and are, with the exception of Sr, very similar for each element. However, the amount of fractional crystallization suggested by $\mathrm{Ti}, \mathrm{Zr}, \mathrm{Ce}, \mathrm{Eu}, \mathrm{Yb}$, and $\mathrm{Hf}(34 \%)$ is over twice that predicted by the least-squares calculations using the major oxides (i.e., 16\%).

Similar attempts to produce Site 424 ferrobasalts from a parental Unit C3 (Hole 425) basalt reveal similar discrepancies in the amount of fractionation predicted by the least-squares calculations using the major oxides, and Rayleigh fractionation calculations on the minor and trace elements. The latter calculations (Table 10) again give consistent results for the incompatible elements ( $\sim 60 \%$ crystallization) which are greater than the degree of crystallization $(\sim 30 \%)$ predicted by the leastsquares calculations. Although it is likely that a small part of these discrepancies result from the linear mathematics of the least-squares mixing equation and the logarithmic mathematics of the Rayleigh equation, we conclude that closed-system fractional crystallization does not satisfactorily explain variations in both the major oxide and trace element data within Hole 425.

Geophysical studies (Rosendahl et al., 1976) along the East Pacific Rise in the Siqueiros area suggest that the crestal region is underlain by a crustal low-velocity zone. Rosendahl et al. (1976) interpret this zone as a large shallow magma chamber which possibly extends for a considerable distance along the axis of the ridge crest. The relatively smooth and non-rifted topography 
TABLE 6

Groundmass Pyroxenes, Section 424-6-1 (Piece 10c)

\begin{tabular}{lcrrrrrrrr}
\hline & 1 & \multicolumn{1}{c}{2} & \multicolumn{1}{c}{3} & \multicolumn{1}{c}{4} & \multicolumn{1}{c}{5} & \multicolumn{1}{c}{6} & 7 & \multicolumn{1}{c}{8} & 9 \\
\hline $\mathrm{SiO}_{2}$ & 51.19 & 52.80 & 52.09 & 52.37 & 53.33 & 49.42 & 49.40 & 49.34 & 47.85 \\
$\mathrm{TiO}_{2}$ & 0.82 & 0.51 & 0.69 & 0.61 & 0.38 & 1.46 & 1.03 & 1.53 & 0.89 \\
$\mathrm{Al}_{2} \mathrm{O}_{3}$ & 2.48 & 1.91 & 2.34 & 1.50 & 1.01 & 3.65 & 2.45 & 3.36 & 1.93 \\
$\mathrm{Cr}_{2} \mathrm{O}_{3}$ & 0.14 & 0.19 & 0.23 & - & - & - & 0.14 & - & - \\
$\mathrm{FeO}$ & 9.38 & 10.63 & 11.45 & 15.18 & 18.20 & 14.90 & 16.94 & 18.63 & 26.01 \\
$\mathrm{MnO}$ & 0.16 & 0.16 & 0.26 & 0.24 & 0.34 & 0.24 & 0.27 & 0.40 & 0.39 \\
$\mathrm{MgO}$ & 15.33 & 17.10 & 17.40 & 18.61 & 22.07 & 13.39 & 11.61 & 8.79 & 14.55 \\
$\mathrm{CaO}$ & 19.17 & 16.70 & 15.54 & 11.29 & 4.38 & 16.41 & 16.97 & 18.87 & 7.64 \\
$\mathrm{CoO}$ & - & 0.18 & 0.23 & 0.23 & 0.33 & 0.11 & 0.30 & 0.31 & 0.40 \\
$\mathrm{Na} 2 \mathrm{O}$ & - & - & - & 0.52 & - & 0.29 & - & 0.57 & - \\
$\mathrm{V}_{2} \mathrm{O}_{5}$ & - & 0.13 & - & - & - & - & 0.13 & 0.14 & 0.19 \\
$\mathrm{Total}$ & 98.68 & 100.31 & 100.23 & 100.57 & 100.05 & 99.88 & 99.25 & 99.96 & 99.85
\end{tabular}

\begin{tabular}{lccccccccc}
$\mathrm{Si}$ & 1.925 & 1.947 & 1.927 & 1.943 & 1.971 & 1.876 & 1.910 & 1.910 & 1.877 \\
$\mathrm{Al} I \mathrm{IV}$ & 0.075 & 0.053 & 0.073 & 0.057 & 0.029 & 0.124 & 0.090 & 0.090 & 0.089 \\
$\mathrm{Al}$ & 0.035 & 0.030 & 0.029 & 0.009 & 0.015 & 0.040 & 0.022 & 0.063 & - \\
$\mathrm{Ti}$ & 0.023 & 0.014 & 0.019 & 0.017 & 0.011 & 0.042 & 0.030 & 0.045 & 0.026 \\
$\mathrm{Cr}$ & 0.004 & 0.005 & 0.007 & - & - & - & - & - & - \\
$\mathrm{Fe}+2$ & 0.295 & 0.328 & 0.354 & 0.471 & 0.563 & 0.473 & 0.548 & 0.603 & 0.853 \\
$\mathrm{Mn}$ & 0.005 & 0.005 & 0.008 & 0.008 & 0.011 & 0.008 & 0.009 & 0.013 & 0.013 \\
$\mathrm{Mg}$ & 0.859 & 0.941 & 0.959 & 1.029 & 1.215 & 0.758 & 0.699 & 0.507 & 0.851 \\
$\mathrm{Ca}$ & 0.772 & 0.660 & 0.616 & 0.449 & 0.173 & 0.665 & 0.703 & 0.700 & 0.321 \\
$\mathrm{Co}$ & - & 0.005 & 0.007 & 0.007 & 0.010 & 0.004 & 0.009 & 0.010 & 0.013 \\
$\mathrm{Na}$ & - & - & - & 0.037 & - & 0.009 & - & 0.043 & - \\
$\mathrm{V}$ & - & 0.004 & - & - & - & - & 0.004 & 0.004 & 0.006 \\
$\mathrm{X}$ & 2.000 & 2.000 & 2.000 & 2.000 & 2.000 & 2.000 & 2.000 & 2.000 & 1.966 \\
$\mathrm{Y}$ & 1.222 & 1.332 & 1.380 & 1.540 & 1.824 & 1.325 & 1.296 & 1.255 & 1.762 \\
$\mathrm{Z}$ & 0.772 & 0.660 & 0.616 & 0.486 & 0.173 & 0.674 & 0.703 & 0.743 & 0.321 \\
$\mathrm{XYZ}$ & 3.994 & 3.992 & 3.999 & 4.026 & 3.997 & 3.999 & 3.999 & 3.988 & 4.049 \\
$\mathrm{Mg} /(\mathrm{Mg}+\mathrm{Fe})$ & 74.4 & 74.1 & 73.0 & 68.6 & 68.4 & 61.6 & 55.0 & 45.6 & 49.9 \\
$\mathrm{Ca}$ & 40.1 & 40.1 & 31.9 & 23.0 & 8.9 & 35.2 & 36.6 & 38.7 & 15.9 \\
$\mathrm{Mg}$ & 44.6 & 44.6 & 49.7 & 52.8 & 62.3 & 39.9 & 34.8 & 28.0 & 42.0 \\
$\mathrm{Fe}$ & 15.3 & 15.3 & 18.4 & 24.2 & 28.8 & 24.9 & 28.6 & 33.3 & 42.1 \\
\hline
\end{tabular}

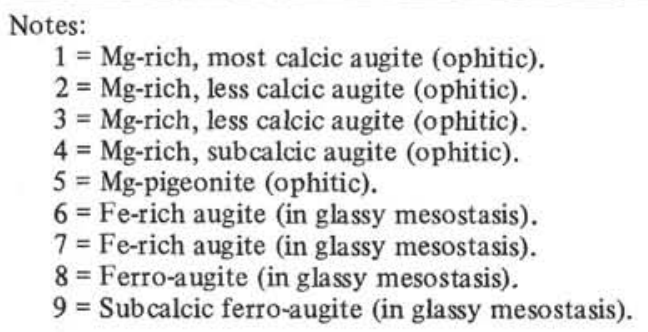

of the East Pacific Rise (and other fast-spreading ridges), in contrast to the rougher, rifted nature of the Mid-Atlantic Ridge, suggest that large axial (and longlived?) magma chambers are characteristic of the ridge systems in the East Pacific area. Batiza et al. (1977) suggest that extensive low-pressure fractional crystallization takes place in these large crustal magma chambers to produce ferrobasalt. They also note the paucity of fractionated tholeiites in the transform fault troughs and suggest that here the magma chamber is absent or severely disrupted.

It seems highly improbable that large, long-lived magma chambers would remain closed systems during the extensive fractionation interval (up to $80 \%$ crystallization) required to generate ferrobasalt, owing to fresh influxes of primitive magma necessary to maintain the magma chamber. Open-system fractionation (O'Hara,
1977), characterized by repeated mixing of fractionated magma with new primitive magma, can result in buffered fractionated compositions dependent on the volume balance between eruptions and replenishment events (O'Hara, 1977; Dungan and Rhodes, 1978). More significantly, Rhodes et al. (1978) show that liquids falling on a mixing line between an unfractionated primitive magma and one that is highly evolved will have higher concentrations of incompatible elements than would be predicted by Rayleigh fractionation. Herein lies a possible explanation for the discrepancies observed in the closed-system modeling calculations.

Unfortunately, there are insufficient trace element data available for primitive liquids from the East Pacific area to fully model open-system fractionation. However, an attempt was made to generate moderately fractionated basalt of similar composition to that from Hole 
TABLE 7

Representative Analyses of East Pacific and Atlantic Basalts

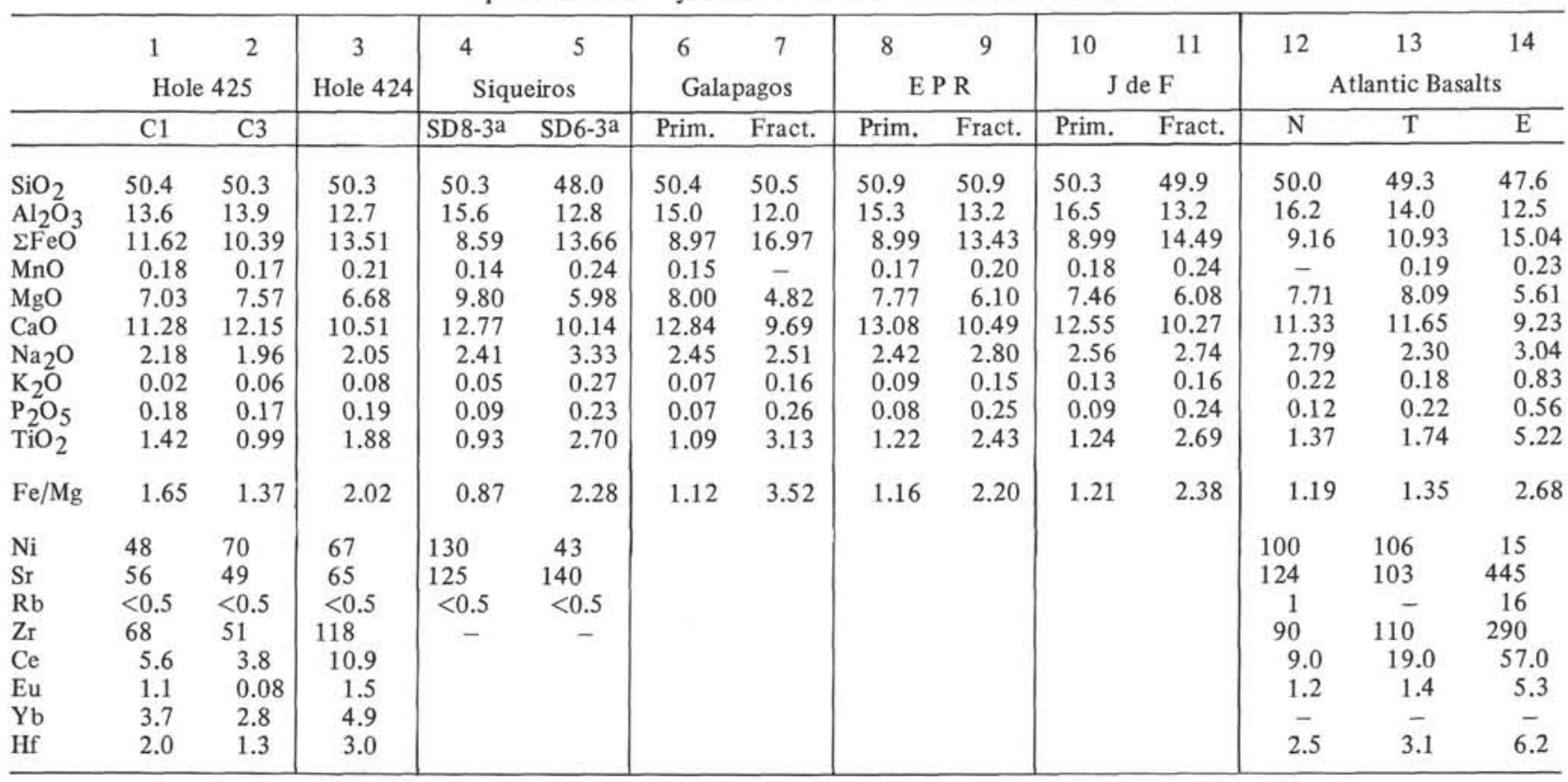

Notes:

1 = Most evolved basalt, Unit C1, Hole 425 .

$2=$ Average of least evolved basalts from Unit C3, Hole 425 .

$3=$ Average ferrobasalt, Hole 424 .

4 = Primitive basalt, Siqueiros fracture zone (Batiza et al., 1977).

$5=$ Ferrobasalt, Siqueiros fracture zone (op. cit.).

$6=$ Average least evolved basalt, dredged from Galapagos Spreading Center (Table 1, Clague and Bunch, 1976).

$7=$ Average most evolved ferrobasalt, Galapagos Spreading Center (op. cit.).

$8=$ Average least evolved basalt, East Pacific Rise (op. cit.).

$9=$ Average most evolved ferrobasalt, East Pacific Rise (op. cit.).

$10=$ Average least evolved basalt, Juan de Fuca Ridge (op. cit.).

$11=$ Average most evolved ferrobasalt, Juan de Fuca Ridge (op. cit.).

12 = Typical depleted "N-type" A tlantic MORB (Table 1, Wood et al., 1979).

13 = Transitional "T-type" MORB (op. cit.).

$14=$ Enriched "E-type" ferrobasalt, Iceland (op. cit.).

425 Unit $\mathrm{C} 1$ basalt by mixing of Site 424 ferrobasalt and least-fractionated Hole 425 Unit C3 basalt. A mix of these end members in the proportions of 30 per cent ferrobasalt to 70 per cent primitive basalt produces a moderately evolved basalt closely similar to 425 Unit C2 basalt in respect of both major oxide and trace elements (Table 11). A mixing model is, therefore, in this case, a significant improvement over a closed-system fractional crystallization model. We postulate that magma mixing plays an important role in the generation of East Pacific ferrobasalts and that an open-system fractionation model would more accurately describe the major oxide and trace element variation observed in the range of basalts erupted along fast-spreading, non-rifted ridges.

\section{CONCLUSIONS}

1) Basalts drilled at $86^{\circ} \mathrm{W}$ close to the Galapagos Spreading Center are moderately evolved basalts and ferrobasalts characteristic of the non-rifted, fastspreading ridge systems in the East Pacific area.

2) Despite strong enrichment of $\mathrm{Fe}, \mathrm{Ti}, \mathrm{Zr}$, and REE, these basalts are fundamentally similar to N-type
MORB (Sun et al., 1979) and were probably generated within a "depleted" mantle source region.

3) Closed-system fractional crystallization does not satisfactorily account for the observed geochemical variation of both the major oxides and trace elements in the moderately evolved basalts from Hole 425 .

4) Mixing of ferrobasalt with more primitive basalt models more successfully the formation of moderately evolved basalts from Hole 425 .

5) Open-system fractionation (O'Hara, 1977), with periodic influx of primitive $\mathrm{N}$-type MORB magma and mixing with evolved ferrobasalt, is a preferred model for the genesis of iron-rich tholeiites erupted at fastspreading ridges.

\section{ACKNOWLEDGMENTS}

DPM is grateful to Dr. J. Long for the use of electronmicroprobe facilities at Cambridge, and to Dr. N. Charnley for assistance in its operation. DPM is also grateful to the Natural Environment Research Council for financial support during this work. 


\section{REFERENCES}

Anderson, A. T., and Greenland, L. P., 1969. Phosphorus fractionation diagram as a quantitative indicator of crystallization differentiation of basaltic liquids. Geochim. Cosmochim. Acta, v. 33, p. 493-505.

Anderson, R. N., Clague, D. A., Klitgord, D. D., Marshall, M., and Nishimori, R. K., 1975. Magnetic and petrologic variations along the Galapagos Spreading Centre, and their relation to the Galapagos melting anomaly. Geol. Soc. Am. Bull., v. 86, p. 683-694.

Arth, J. G., and Hanson, G. N., 1975. Geochemistry and origin of the early Precambrian Crust of northeastern Minnesota. Geochim. Cosmochim. Acta, v. 39, p. 325-362.

Barberi, F., Bizouard, H., and Varet, J., 1971. Nature of the clinopyroxene and iron enrichment in alkalic and transitional basaltic magmas. Contrib. Mineral. Petrol., v. 33, p. 93-107.

Batiza, R., Rosendahl, B. R., and Fisher, R. L., 1977. Evolution of oceanic crust, Part III: Petrology and chemistry of basalts from the East Pacific Rise and Siqueiros fracture zone. J. Geophys. Res., v. 82, p. 265-276.

Bougault, H., Cambon, P., Corre, D., Joron, J. L., and Treuil, M., 1979. Evidence for variability of magmatic processes and upper mantle heterogeneity in the axial region of the Mid-Atlantic Ridge near $22^{\circ} \mathrm{N}$ and $36^{\circ} \mathrm{N}$. Tectonophysics, v. 55, p. 314-323.

Bunch, T. E., and Laborde, R., 1976. Mineralogy and compositions of selected basalts from DSDP Leg 34. In Yeats, R. S., Hart, S. R., et al., Initial Reports of the Deep Sea Drilling Project, v. 34: Washington (U.S. Government Printing Office), p. 263-276.

Cawthorn, R. G., and Collerson, K. D., 1974. The recalculation of pyroxene end member parameters and the estimation of ferrous and ferric iron content from electron microprobe analyses. Am. Mineral., v. 59, p. 1203-1208.

Cawthorn, R. G., Ford, C. E., Biggar, G. M., Bravo, M. S., and Clarke, D. B., 1973. Determination of the liquid composition in experimental samples: discrepancies between microprobe and other methods. Earth Planet. Sci. Lett., v. 31, p. $1-5$.

Clague, D. A., and Bunch, T. E., 1976. Formation of ferrobasalt at East Pacific Midocean spreading centres. J. Geophys. Res., v. 81, p. 4246-4256.

Coish, R. A., and Taylor, L. A., 1979. The effects of cooling rate on texture and pyroxene chemistry in DSDP Leg 34 basalt: A microprobe study. Earth Planet. Sci. Lett., v. 42, p. 389-398.

Dietrick, R. S., and Lynn, W. S., 1975. The origin of high amplitude magnetic anomalies at the intersection of the Juan de Fuca Ridge and Blanco Fracture Zone. Ibid. v. 26, p. 105-113.

Donaldson, C. H.,Usselman, T. M., Williams, R. J., and Lofgren, G. E., 1975. Experimental modelling of the cooling history of Apollo 12 basalts. Proc. 6th Lunar Sci. Conf., p. 843-869.

Dungan, M. A., and Rhodes, J. M., 1978. Residual glasses and melt inclusions in basalts from DSDP Leg 45 and 46: Evidence for magma mixing. Contrib. Mineral. Petrol., v. 67, p. 417-431.

Fodor, R. V., Kiel, K., and Bunch, T. E., 1975. Contributions to the mineral chemistry of Hawaiian rocks from Haleakala and West Maui Volcanoes. Ibid., v. 50, p. 173-195.

Gordon, G. E., Randle, K., Coles, G. G., Corliss, J. B., Beeson, M. H., and Oxley, S. S., 1968. Instrumental activation analysis of standard rocks with high resolution on X-ray detectors. Geochim. Cosmochim. Acta, v. 32, p. 369-396.
Kay, R., Hubbard, N. J., and Gast, P. W., 1970. Chemical characteristics and origin of oceanic ridge volcanic rocks. $J$. Geophys. Res., v. 75, p. 1585-1613.

Kempe, D. R. C., 1976. Petrological studies on DSDP Leg 34 basalts, Nazca Plate, Eastern Pacific Ocean. In Yeats, R. S., Hart, S. R., et al., Initial Reports of the Deep Sea Drilling Project, v. 34: Washington (U.S. Government Printing Office), p. 189-214.

Lofgren, G. E., 1974. An experimental study of plagioclase morphology: isothermal crystallization. Am. J. Sci., v. 276, p. 243-273.

Lofgren, G. E., Donaldson, C. H., and Usselman, T. M., 1974. Experimentally reproduced textures and mineral chemistry of Apollo 15 quartz-normative basalts. Proc. 5th Lunar Sci. Conf., p. 79-100.

Mattey, D. P., 1980. The petrology of high-calcium low alkali tholeiite dykes from the regional swarm of the Isle of Skye, Scotland. Ph.D. thesis (unpublished), University of London.

Mattey, D. P., Marsh, N. G., and Tarney, J., in press. The geochemistry, mineralogy, and petrology of basalts from the West Philippine and Parece-Vela basins and from the Kyushu-Palau and West Mariana ridges, IPOD Leg 59. In Scott, R. B., Kronke, L., et al. Initial Reports of the Deep Sea Drilling Project, v. 59: Washington (U.S. Government Printing Office).

Mevel, C., and Velde, D., 1976. Clinopyroxenes in Mesozoic pillow lavas from the French Alps: influence of cooling rate on compositional trends. Earth Planet. Sci. Lett., v. 32, p. 158-164.

Muir, I. D., 1954. Crystallization of pyroxenes from an ironrich diabase from Minnesota. Mineral. Mag., v. 30, p. 376-388.

Muir, I. D., and Tilley, C. E., 1964. Iron enrichment and pyroxene fractionation in tholeiite. Geol. J., v. 4, p. 143-156.

Mysen, B. O., and Heier, K. S., 1972. Petrogenesis of eclogites in high grade metamorphic gneisses, exemplified by the Hareidland eclogite, western Norway. Contrib. Mineral. Petrol., v. 36, p. 73-94.

Nakamura, K., 1974. Determination of REE, Ba, Fe, Mg, Na and $\mathrm{K}$ in carbonaceous and ordinary chondrites. Geochim. Cosmochim. Acta, v. 38, p. 757-775.

O'Hara, M. J., 1977. Geochemical evolution during fractional crystallisation of a periodically refilled magma chamber. Nature, v. 266, p. 503-507.

Papike, J. J., Cameron, K. L., and Baldwin, K., 1976. Amphiboles and pyroxenes - characterisation of other than quadrilateral components. Geol. Soc. Abs., v. 6, p.10531054.

Pearce, J. A., and Norry, M. J., 1979. Petrogenetic implications of $\mathrm{Ti}, \mathrm{Zr}, \mathrm{Y}$ and $\mathrm{Nb}$ variations in volcanic rocks. Contrib. Mineral. Petrol., v. 69, p. 33-47.

Philpotts, J. A., and Schnetzler, C. C., 1970. Phenocryst matrix partition coefficients for $\mathrm{K}, \mathrm{Rb}, \mathrm{Sr}$ and $\mathrm{Ba}$ with applications to anorthosite and basalt genesis. Geochim. Cosmochim. Acta, v. 34, p. 307-322.

Rhodes, J. M., Blanchard, D. P., Dungan, M. A., Rodgers, K. V., and Brannon, J. C., 1978. Chemistry of basalts from Leg 45 of the Deep Sea Drilling Project. In Melson, W., Rabinowitz, W. et al., Initial Reports of the Deep Sea Drilling Project, v. 45: Washington (U. S. Government Printing Office), p. 447-460.

Roeder, P. L., and Emslie, P. F., 1970. Olivine-liquid equilibrium. Contrib. Mineral. Petrol., v. 29, p. 275-289.

Rosendahl, B. R., Raitt, R. W., Donnan, L. M., Bibee, L. D., Hussong, D. M., and Sutton, G. H., 1976. Evolution of oceanic crust, 1, A geophysical model of the East Pacific 
Rise Crest from seismic-refraction data. J. Geophys. Res., v. 82 , p. $5294-5304$.

Routi, J. T., 1969. SAMPO, a FORTRAN IV programme for computer analysis of gamma spectra from $\mathrm{Ge}(\mathrm{Li})$ detectors, and other spectra with peaks. Am. Govt. Rep. UCRL19452.

Schilling, J. G., Anderson, R. N., and Vogt, P., 1976. Rare earth, $\mathrm{Fe}$ and $\mathrm{Ti}$ variations along the Galapagos spreading centre, and their relationship to the Galapagos mantle plume. Nature, v. 261, p. 108-113.

Simkin, T., and Smith, J. V., 1970. Minor element distribution in olivine. J. Geol., v. 178, p. 304-325.

Smith, P., and Lindsley, D. H. 1971. Stable and metastable augite crystallisation trends in a single basalt flow. $\mathrm{Am}$. Mineral., v. 586, p. 225-233.

Sun, S-S., Nesbitt, R., and Sharaskin, A. Ya., 1979. Geochemical characteristics of ocean ridge basalts. Earth Planet. Sci. Lett., v. 44, p. 119-138.

Tarney, J., Wood, D. A., Saunders, A. D., Cann, J. R., and Varet, J., in press. Nature of mantle heterogeneity in the North Atlantic: Evidence from Deep Sea Drilling. Phil. Trans. Roy Soc. Lond.

Tarney, J., Wood, D. A., Saunders, A. D., Varet, J., and Cann, J. R., 1979. Nature of mantle heterogeneity in the north atlantic: evidence Leg 49. In Talwani, M. (Ed.), Implications of Deep Sea Drilling Results in the Atlantic Ocean, Maurice Ewing Series, v. 2: Washington (American Geophysical Union). p. 285-301.

Wood, D. A., Joron, J. L., Marsh, N. G., Tarney, J., and Treuil, M., in press. Major and trace element variations in basalts from the North Philippine Sea drilled during DSDP Leg 58: A comparitive study of Back-arc basin basalts with lava series from Japan and mid-oceanic ridges. In Klein, G., Kobayashi, K., et al. Initial Reports of the Deep Sea Drilling Project, v. 58: Washington (U. S. Government Printing Office).

Wright, T. L., and Doherty, P. C. 1970. A linear programming and least squares computer method for solving petrological mixing problems. Geol. Soc. Am. Bull., v. 81, p.1995-2008.

Yamakawa, M., 1971. Two different crystallisation trends of pyroxene in a tholeiitic dolerite, Semi, Northern Japan. Contrib. Mineral. Petrol., v. 33, p. 232-238.
TABLE 8

Least-Squares Crystal Fractionation Solutions

\begin{tabular}{|c|c|c|c|c|c|c|c|}
\hline \multicolumn{8}{|c|}{ Unit $\mathrm{C} 3$ to Unit $\mathrm{C} 2$} \\
\hline & $\mathrm{C} 2$ & Fo85 & An 84 & $\mathrm{Cpx}$ & $\mathrm{C} 3$ & $\begin{array}{l}\text { Calcu- } \\
\text { lated }\end{array}$ & \\
\hline $\mathrm{SiO}_{2}$ & 50.57 & 40.82 & 48.82 & 53.41 & 50.35 & 50.61 & -0.26 \\
\hline $\mathrm{Al}_{2} \mathrm{O}_{3}$ & 13.88 & & 33.66 & 2.66 & 13.89 & 13.99 & -0.10 \\
\hline$\Sigma \mathrm{FeO}$ & 10.75 & 14.62 & 0.43 & 6.66 & 10.39 & 10.44 & -0.05 \\
\hline $\mathrm{MgO}$ & 7.53 & 46.33 & 0.12 & 18.58 & 7.57 & 7.66 & -0.09 \\
\hline $\mathrm{CaO}$ & 11.90 & 0.28 & 16.76 & 17.89 & 12.15 & 12.15 & 0.00 \\
\hline $\mathrm{Na}_{2} \mathrm{O}$ & 2.08 & & 1.71 & & 1.96 & 2.02 & -0.06 \\
\hline $\mathrm{K}_{2} \mathrm{O}$ & 0.02 & & & & 0.06 & 0.02 & 0.04 \\
\hline $\mathrm{TiO}_{2}$ & 1.18 & & & 0.36 & 0.98 & 1.14 & -0.16 \\
\hline $\mathrm{P}_{2} \mathrm{O}_{5}$ & 0.09 & & & & 0.08 & 0.09 & -0.01 \\
\hline $\mathrm{MnO}$ & 0.18 & 0.14 & & 0.14 & 0.17 & 0.18 & -0.01 \\
\hline Solution ${ }^{\mathrm{a}}$ & 0.955 & - & 0.020 & 0.025 & & & 20.1168 \\
\hline
\end{tabular}

Unit $\mathrm{C} 3$ to Unit $\mathrm{Cl}$

\begin{tabular}{|c|c|c|c|c|c|c|c|}
\hline & $\mathrm{C} 1$ & Fo85 & An 84 & Cpx & C3 & $\begin{array}{l}\text { Calcu- } \\
\text { lated }\end{array}$ & $r$ \\
\hline $\mathrm{SiO}_{2}$ & 50.44 & 40.82 & 48.82 & 53.41 & 50.35 & 50.55 & -0.20 \\
\hline $\mathrm{Al}_{2} \mathrm{O}_{3}$ & 13.55 & & 33.66 & 2.66 & 13.99 & 13.98 & -0.09 \\
\hline $\mathrm{EFeO}$ & 11.63 & 14.62 & 0.43 & 6.66 & 10.39 & 10.45 & -0.06 \\
\hline $\mathrm{MgO}$ & 7.03 & 46.33 & 0.12 & 18.58 & 7.57 & 7.65 & -0.08 \\
\hline $\mathrm{CaO}$ & 11.28 & 0.28 & 16.76 & 17.89 & 12.15 & 12.18 & -0.03 \\
\hline $\mathrm{Na}_{2} \mathrm{O}$ & 2.18 & & 1.71 & & 1.96 & 1.96 & 0.00 \\
\hline $\mathrm{K}_{2} \mathrm{O}$ & 0.02 & & & & 0.06 & 0.02 & 0.04 \\
\hline $\mathrm{TiO}_{2}$ & 1.42 & & & 0.36 & 0.98 & 1.23 & -0.25 \\
\hline $\mathrm{P}_{2} \mathrm{O}_{5}$ & 0.09 & & & & 0.08 & 0.08 & 0.00 \\
\hline $\mathrm{MnO}$ & 0.18 & 0.14 & & 0.14 & 0.17 & 0.16 & 0.01 \\
\hline Solution $b$ & 0.844 & 0.003 & 0.069 & 0.084 & & \multicolumn{2}{|c|}{$\Sigma r^{2} 0.1219$} \\
\hline
\end{tabular}

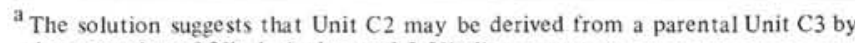
the separation of $2 \%$ plagioclase and $2.5 \%$ clinopyroxene.

b The solution suggests that Unit $\mathrm{Cl}$ may be derived from a parental Unit $\mathrm{C} 3$ by the separation of $0.3 \%$ olivine, $6.9 \%$ plagioclase, and $8.4 \%$ clinopyroxene.

TABLE 9

Distribution Coefficients for Phenocrysts and Basaltic Matrix ${ }^{a}$

\begin{tabular}{lcccccccc}
\hline & $\mathrm{Ti}$ & $\mathrm{Zr}$ & $\mathrm{Sr}$ & $\mathrm{Ni}$ & $\mathrm{Ce}$ & $\mathrm{Eu}$ & $\mathrm{Yb}$ & $\mathrm{Hf}^{\mathrm{f}}$ \\
\hline Olivine & $0.01^{\mathrm{b}}$ & $0.01^{\mathrm{b}}$ & $0.01^{\mathrm{b}}$ & $10^{\mathrm{c}}$ & 0.01 & 0.01 & 0.02 & $0.01^{\mathrm{b}}$ \\
Plagioclase & $0.01^{\mathrm{b}}$ & $0.01^{\mathrm{b}}$ & 2.0 & 0.01 & 0.08 & 0.34 & 0.07 & $0.01^{\mathrm{b}}$ \\
Clinopyroxene & 0.5 & 0.1 & 0.12 & $2^{\mathrm{c}}$ & 0.15 & 0.51 & 0.62 & $0.01^{\mathrm{b}}$ \\
\hline
\end{tabular}

a Sources: Pearce and Norry (1979); Arth and Hanson (1975); Philpotts and Schnetzler (1970).

b Assumed values.

${ }^{\circ}$ Calculated for $\mathrm{T}=1300^{\circ} \mathrm{C}$. 
TABLE 10

Rayleigh Fractionation Calculations

\begin{tabular}{|c|c|c|c|c|c|c|}
\hline & $\begin{array}{c}\text { Parent } \\
\text { C3 }\end{array}$ & $\begin{array}{c}\text { Frac- } \\
\text { tionate } \\
\mathrm{Cl}\end{array}$ & $D$ & $F$ & $\begin{array}{c}\text { Frac- } \\
\text { tionate, } \\
\text { Site } 424\end{array}$ & $F$ \\
\hline $\mathrm{Ti}$ & 0.99 & 1.42 & 0.032 & 0.69 & 1.88 & 0.52 \\
\hline $\mathrm{Zr}$ & 0.51 & 0.68 & 0.010 & 0.75 & 0.118 & 0.43 \\
\hline $\mathrm{Sr}$ & 0.49 & 0.56 & 0.949 & $(0.07)$ & 0.065 & $(0.00)$ \\
\hline $\mathrm{Ni}$ & 0.70 & 0.48 & 1.270 & 0.25 & 0.067 & 0.85 \\
\hline $\mathrm{Ce}$ & 3.80 & 5.58 & 0.116 & 0.65 & 10.87 & 0.30 \\
\hline $\mathrm{Eu}$ & 0.83 & 1.14 & 0.425 & 0.58 & 1.50 & 0.36 \\
\hline $\mathrm{Yb}$ & 2.81 & 3.66 & 0.363 & 0.66 & 4.93 & 0.41 \\
\hline $\mathrm{Hf}$ & 1.26 & 2.02 & 0.010 & 0.62 & 2.95 & 0.42 \\
\hline Mean & & & & $0.66^{\mathrm{a}}$ & & $0.41^{\mathrm{a}}$ \\
\hline \multicolumn{7}{|c|}{ Predicted from } \\
\hline \multicolumn{4}{|c|}{ least-squares calculation: } & 0.84 & & $(0.70)$ \\
\hline
\end{tabular}

Note: $F$ calculated from the Rayleigh calculation: $C / C o=$ $F(\mathrm{D}-1)$, where $C$ is concentration of element in fractionated liquid, and $\mathrm{Co}$ is concentration of element in parent liquid. $D$ is bulk distribution coefficient for an assemblage composed of $2 \%$ olivine, $44 \%$ plagioclase, and $54 \%$ clinopyroxene.

${ }^{\mathrm{a}}$ Excluding the results for $\mathrm{Sr}$ and $\mathrm{Ni}$.

TABLE 11

Mixing Model

\begin{tabular}{lccc}
\hline & C1 & Mix & Ray. \\
\hline $\mathrm{SiO}_{2}$ & 50.4 & 50.4 & \\
$\mathrm{Al}_{2} \mathrm{O}_{3}$ & 13.6 & 13.5 & \\
$\Sigma \mathrm{FeO}$ & 11.62 & 11.33 & \\
$\mathrm{MnO}$ & 0.18 & 0.18 & \\
$\mathrm{MgO}$ & 7.03 & 7.30 & \\
$\mathrm{CaO}$ & 11.28 & 11.66 & \\
$\mathrm{Na}{ }_{2} \mathrm{O}$ & 2.18 & 2.00 & \\
$\mathrm{~K}_{2} \mathrm{O}$ & 0.02 & 0.07 & \\
$\mathrm{P}_{2} \mathrm{O}_{5}$ & 0.18 & 0.18 & \\
$\mathrm{TiO}_{2}$ & 1.42 & 1.26 & 1.16 \\
$\mathrm{FeO} / \mathrm{MgO}$ & 1.65 & 1.55 & \\
$\mathrm{Ni}$ & 48 & 69 & 66 \\
$\mathrm{Sr}$ & 54 & 56 & 49 \\
$\mathrm{Zr}$ & 68 & 71 & 60 \\
$\mathrm{Ce}$ & 5.58 & 5.92 & 4.42 \\
$\mathrm{Eu}$ & 1.14 & 1.03 & 0.92 \\
$\mathrm{Yb}$ & 3.66 & 3.45 & 3.13 \\
$\mathrm{Hf}$ & 2.02 & 1.77 & 1.49 \\
\hline
\end{tabular}

Note: "Mix" is a linear mix of $70 \%$ least evolved Hole 425 Unit $\mathrm{C} 3$ basalt and $30 \%$ average Site 424 ferrobasalt. "Ray." is the concentration of elements calculated using the Rayleigh fractionation equation resulting from $16 \%$ fractional crystallization of an assemblage composed of $2 \%$ olivine, $44 \%$ plagioclase, and $54 \%$ clinopyroxene (i.e., the results of the leastsquares fractionation step from Unit C3 to Unit C1). It is clear that the hybrid composition "Mix" is similar to that of the moderately evolved Hole 425 Unit C1 basalt in terms of major and trace elements. 